\title{
Therapeutic Targeting of DNA Damage Response in Cancer
}

\author{
Wonyoung Choi ${ }^{1,2}$ and Eun Sook Lee ${ }^{1,3, *}$ \\ 1 Research Institute, National Cancer Center, Goyang 10408, Korea; wonyoungchoi@ncc.re.kr \\ 2 Center for Clinical Trials, National Cancer Center, Goyang 10408, Korea \\ 3 Center for Breast Cancer, National Cancer Center, Goyang 10408, Korea \\ * Correspondence: eslee@ncc.re.kr; Tel.: +82-31-920-1633
}

check for

updates

Citation: Choi, W.; Lee, E.S.

Therapeutic Targeting of DNA

Damage Response in Cancer. Int. J.

Mol. Sci. 2022, 23, 1701. https://

doi.org/10.3390/ijms23031701

Academic Editor: Frank Thévenod

Received: 29 December 2021

Accepted: 29 January 2022

Published: 1 February 2022

Publisher's Note: MDPI stays neutral with regard to jurisdictional claims in published maps and institutional affiliations.

Copyright: (C) 2022 by the authors. Licensee MDPI, Basel, Switzerland. This article is an open access article distributed under the terms and conditions of the Creative Commons Attribution (CC BY) license (https:// creativecommons.org/licenses/by/ $4.0 /)$.

\begin{abstract}
DNA damage response (DDR) is critical to ensure genome stability, and defects in this signaling pathway are highly associated with carcinogenesis and tumor progression. Nevertheless, this also provides therapeutic opportunities, as cells with defective DDR signaling are directed to rely on compensatory survival pathways, and these vulnerabilities have been exploited for anticancer treatments. Following the impressive success of PARP inhibitors in the treatment of BRCA-mutated breast and ovarian cancers, extensive research has been conducted toward the development of pharmacologic inhibitors of the key components of the DDR signaling pathway. In this review, we discuss the key elements of the DDR pathway and how these molecular components may serve as anticancer treatment targets. We also summarize the recent promising developments in the field of DDR pathway inhibitors, focusing on novel agents beyond PARP inhibitors. Furthermore, we discuss biomarker studies to identify target patients expected to derive maximal clinical benefits as well as combination strategies with other classes of anticancer agents to synergize and optimize the clinical benefits.
\end{abstract}

Keywords: DNA damage response; homologous recombination; BRCA; PARP inhibitor; ATM; ATR; DNA-PK; CHK1; CHK2; WEE1

\section{Introduction}

Human cancer is caused by genetic changes that cause uncontrolled cell proliferation [1]. Mutations occur as a result of DNA replication errors or inappropriately repaired DNA damage. Various cell-intrinsic mechanisms minimize the changes in DNA, and most steadily acquired somatic mutations are harmless; however, a small portion of these mutations can confer a selective advantage to the cell, which could allow the cell to grow or survive preferentially. The rates of mutational processes vary widely, but most human cancers carry 1000 to 20,000 point mutations and several hundreds of insertions, deletions, and rearrangements [2-4].

Accumulation of aberrant somatic mutations can trigger malignant cell transformation. Thus, human cells have evolved to prevent these errors via multiple layers of repair mechanisms. DNA damage response (DDR) pathways meticulously restore damaged sequences or direct irreparably damaged cells to undergo apoptosis or senescence. Genomic instability is an important hallmark of cancer, and defects in the DDR pathway may promote the growth of cancer cells by inducing de novo driver mutations, generating tumor heterogeneity, and evading apoptosis $[1,5,6]$.

Ironically, however, defects in DDR machinery also provide therapeutic opportunities. As the pharmacologic blockade of the DDR signaling cascade directs tumor cells to rely on compensatory survival pathways, these vulnerabilities have been exploited in anticancer therapies [6]. The use of PARP inhibitors in BRCA-mutated cancers represents a successful example of this strategy, and more recently, the development of potent and selective agents that target DDR signaling components is rapidly emerging as a promising therapeutic option. 
Here, we summarize the key elements of the DDR pathway and how these molecular components may serve as anticancer targets. We also discuss the recent development of promising new agents that target the DDR pathway, biomarker studies to patient cohorts that are expected to derive clinical benefits from their use, and ongoing preclinical and clinical investigations to optimize these strategies.

\section{Mechanisms of DNA Damage Response}

Cells have various DNA repair mechanisms that act upon different kinds of genotoxic stress. In this section, we describe how various types of DNA damage are meticulously repaired, depending on the site of the damaged sequence and the type of damage.

\subsection{Single-Strand Break}

\subsubsection{Base Excision Repair (BER)}

BER corrects small single-strand breaks (SSBs) that do not distort the DNA helix [7]. The first step of BER is to remove the damaged bases from the double helix. DNA glycosylase is a group of enzymes that recognize specific types of altered bases in DNA and cleaves the bond between deoxyribose and the damaged base. This creates an AP site (which stands for apurinic or apyrimidinic) that is recognized by AP endonuclease, removing the phosphodiester backbone. Then, poly (ADP-ribose) polymerase 1 (PARP1) and X-ray repair cross-complementing protein 1 (XRCC1) engage in the gap, promoting the assembly of repair factors. DNA polymerase $\beta(\mathrm{Pol} \beta)$ or DNA polymerase $\lambda(\operatorname{Pol} \lambda)$ conducts gap filling, followed by ligation by DNA ligase I or III [7-9].

\subsubsection{Nucleotide Excision Repair (NER)}

NER is the main DNA repair system for the removal of bulky single-strand lesions that distort the DNA helical structure, mainly caused by ultraviolet irradiation or chemical compounds [10,11]. NER involves two major pathways: global genome NER (GG-NER) and transcription-coupled NER (TC-NER). GG-NER occurs anywhere in the genome, whereas TC-NER is responsible for the efficient repair of DNA lesions in the transcribed strand of active genes. GG-NER starts with recognition of helix-distorting lesions by the xeroderma pigmentosum $\mathrm{C}$ (XPC) complex, which is an indirect sensor for structural changes, and requires verification of whether the lesion should be repaired. TC-NER is initiated when RNA polymerase II stalls upon recognition of single-stranded lesions, causing helix-distortion [12]. These two subtypes of NER share a common pathway for further processing of DNA repair. The DNA-dependent ATPase/helicase transcription factor IIH (TFIIH) complex verifies the presence of damaged lesions. Subsequently, the structurespecific endonucleases, xeroderma pigmentosum group $\mathrm{F}$ protein (XPF), excision repair cross-complementation group 1 (ERCC1) complex, and xeroderma pigmentosum group G protein (XPG) incise the damaged strand, leaving a single-strand gap of 22-30 nucleotides. Finally, the gap is filled with DNA polymerase and ligase activities $[11,13,14]$.

\subsection{Double-Strand Break (DSB)}

Damage to both strands of the DNA is especially dangerous because there is no intact template strand to ensure accurate repair. Ionizing radiation, replication errors, or reactive oxygen species may cause these types of DSBs. When left unrepaired, it quickly leads to chromosome breakdown. However, two distinct mechanisms, discussed below, have evolved to maintain genome integrity.

\subsubsection{Non-Homologous End Joining (NHEJ)}

NHEJ is the simplest way to repair DSBs, as the broken ends are joined by DNA ligation with the resultant loss of nucleotides at the joining site [15-17]. Although it causes inevitable changes in the DNA sequence, most DSBs that occur in human cells are repaired by NHEJ [16]. The first step of NHEJ starts with the recognition of the DSBs by the $\mathrm{Ku} 70-\mathrm{Ku} 80$ heterodimer $(\mathrm{Ku})$, which acts as a loading protein for recruiting other NHEJ 
components and promoting the repair process. Subsequently, DNA-dependent protein kinase (DNA-PK) catalytic subunit (DNA-PKcs) directly interacts with Ku to form the DNA-PK complex [15-17]. Because most DSBs result in two incompatible DNA ends with mismatching overhangs, subsequent end resection by endonuclease Artemis and nucleotide addition with DNA polymerases $\mu(\operatorname{Pol} \mu)$ and $\lambda,(\operatorname{Pol} \lambda)$ are necessary. Finally, the DNA ligase IV complex, consisting of X-ray repair cross-complementing 4 (XRCC4), XRCC4-like factor (XLF), and PAXX, a paralog of XRCC4 and XLF, performs the pivotal ligation step [15-17].

Due to its major role in repairing DSBs, loss of function in core NHEJ components has been demonstrated to drive carcinogenesis in murine models. Knockout mice of $\mathrm{Ku} 70, \mathrm{Ku} 80$, or DNA-PKcs are known to have a high incidence of lymphomas [18-20]. Nevertheless, the loss of core NHEJ components is rarely identified in human cancers. Unlike other organisms, $\mathrm{Ku}$ is considered an essential gene in humans as the genetic depletion of human cells with $\mathrm{Ku}$ subunits results in cell death, considered to be caused by the loss of telomere [21,22].

\subsubsection{Homologous Recombination (HR)}

$\mathrm{HR}$ is a much more accurate way to repair DSBs than NHEJ as it precisely restores the original DNA sequence. DSBs can result from radiation or chemical damage but mostly arise from stalled DNA replication forks, irrespective of external stimuli. In general, sister chromatids are used as templates for the accurate repair of the original sequence. The damaged DNA has to be in close proximity to the template DNA for HR-directed repair to occur, and, for this reason, it occurs mainly in the $S$ and G2 phases of the cell cycle when the two daughter DNA strands are sufficiently close to each other to serve as templates for each other [23]. In HR, the DSB ends are recognized by the meiotic recombination 11-RAD50Nijmegen breakage syndrome 1 (MRN) complex, which initiates resection on one strand to generate $3^{\prime}$ single-stranded DNA (ssDNA) overhangs. Subsequently, the ssDNA-binding replication protein A (RPA) coats the overhangs of the breakage site, suppressing further resection. At this point, the DNA damage checkpoint machinery is switched on to arrest the cell cycle and stall the replication fork. The MRN complex at the DSB ends interacts with ataxia-telangiectasia mutated (ATM) kinase, and the RPA-coated ssDNA overhangs recruit and activate ATM and Rad3-related protein (ATR); both are key components in the regulation of the DDR [24]. The DNA strand exchange protein RAD51 subsequently binds to ssDNA to form a protein-DNA filament. This nucleoprotein filament binds to the template double-stranded DNA by stretching the duplex, pulling the strands apart and forming an intermediate structure known as the displacement loop (D-loop). At this point, breast cancer 1 (BRCA1), breast cancer 2 (BRCA2), and partner and localizer of BRCA2 (PALB2) proteins interact to promote RAD51 filament assembly and stimulate strand invasion [23]. The invading strand then searches for sequence homology by conventional base pairing, and, with an extended stretch of base pairing of at least 15 nucleotides, the invading strand is stabilized for DNA synthesis. After sufficient elongation, the invading strand is disengaged from the D-loop and returns to the ssDNA. The DSBs are then annealed with sequence homology created from the DNA synthesis steps within the D-loops [23,25].

Defects in the HR pathway have been highlighted, mostly with loss-of-function mutations of $B R C A 1$ and $B R C A 2$, as germline mutations of these genes are significant risk factors for hereditary breast and ovarian cancers. BRCA1 and BRCA2 proteins are ubiquitously expressed without significant difference in the expression levels between human tissue types [26]. However, it has been highly intriguing to determine how these mutations predominantly transform cells in the breast and ovary. Although the exact molecular basis remains to be elusive, multiple lines of reports have suggested the role of hormones and tissue-specific DNA-damaging metabolites as the background for tissue-specific tumorigenesis $[26,27]$. 


\subsection{DNA Damage Response Signaling}

To maintain genome stability, highly coordinated signaling pathways are activated upon DNA damage. DDR signaling recognizes DNA breaks and arrests cell cycle progression to promote DNA repair; alternatively, it activates pathways that lead to apoptosis or senescence in cases of extensive or irreparable damage. Upstream regulation of DDR signaling is mediated by ATM, ATR, and DNA-PKcs, which are phosphoinositide 3 kinase (PI3K)-related protein kinases (Figure 1).

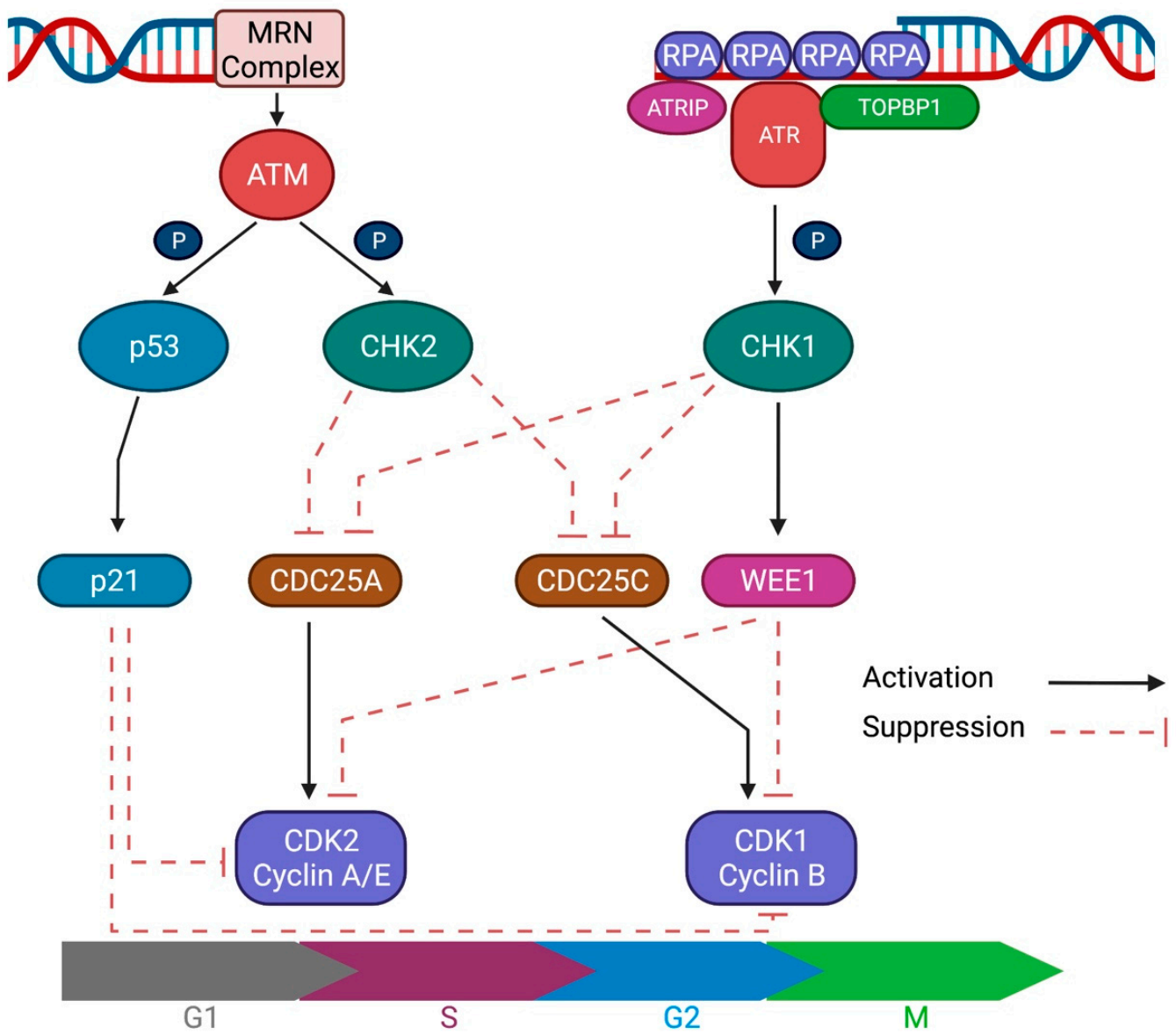

Figure 1. Schematic figure of ATM and ATR signaling. DNA damage response (DDR) signaling recognizes double-strand or single-strand breaks and arrests cell cycle progression to promote DNA repair. ATM and ATR are the key upstream regulators of the DDR signaling cascade.

ATM, a key regulator of DDR, is activated by DSBs and HR. The MRN complex at the DSB recruits and directly binds to and activates ATM, prompting a cascade of DDR signaling via its kinase activity. The most important step is phosphorylation of the Ser-139 residue of the $\mathrm{H} 2 \mathrm{~A}$ histone family member $\mathrm{X}(\mathrm{H} 2 \mathrm{AX})$, forming $\gamma \mathrm{H} 2 \mathrm{AX}$, which is required for the accumulation of chromatin remodeling complexes and DNA repair proteins. Subsequently, $\gamma \mathrm{H} 2 \mathrm{AX}$ recruits mediator of DNA damage checkpoint protein 1 (MDC1) and eventually triggers the phosphorylation-ubiquitylation cascade for DDR signaling [24,28]. ATM also regulates cell cycle checkpoints by the phosphorylation of checkpoint kinase 2 (CHK2) at the G2/M transition and p53 at the G1/S transition [29]. These mechanisms enable cell cycle arrest to promote DNA damage repair or lead to senescence or apoptosis in cases of irreversible damage.

ATR is an important DNA replication stress response kinase that is activated by a wide range of genotoxic stresses. ATR is recruited to DNA breakage sites via direct interaction with ATR-interacting protein (ATRIP), which recognizes RPA-coated ssDNA that arise from resected DSBs or NER intermediates. After localization to the breakage 
site, additional factors, such as DNA topoisomerase II binding protein 1 (TOPBP1) or Ewing's tumor-associated antigen 1 (ETAA1), are required to activate ATR. Activated ATR phosphorylates numerous downstream molecules with checkpoint kinase 1 (CHK1), which is a key target for the regulation of checkpoint signaling [24,29,30]. Upon activation, CHK1 further phosphorylates cell division cycle 25 homolog A (CDC25A), leading to ubiquitination and degradation. As CDC25A is a phosphatase that removes inhibitory modifications from cyclin-dependent kinases (CDKs), $\mathrm{CHK} 1$ activation results in cell cycle arrest. CHK1 also phosphorylates and stabilizes WEE1, a kinase that inactivates CDK1 and CDK2. Therefore, the net effect of CHK1 kinase activation is cell cycle arrest at the G2/M checkpoint [30]. The Aurora kinase A (AURKA) and Polo-like kinase 1 (PLK1) axis adds another layer of G2/M checkpoint regulation [31]. AURKA and its cofactor BORA activate PLK1 by phosphorylating its Thr-210 residue, which then activates CDC25 and suppresses WEE1 to override the G2/M checkpoint [32-34]. Thus, the AURKA-PLK1 axis is inhibited upon DNA damage, serving as another important layer of cell cycle regulation. The DNA$\mathrm{PK} c \mathrm{~s}$ is recruited to DSBs by the Ku heterodimer to form the protein complex DNA-PK, modulating the critical steps in NHEJ, as described in Section 2.2.1. The kinase activity of the DNA-PKcs suppresses DSB-induced and spontaneous HR, thereby directing the repair process towards NHEJ [35]. However, the DNA-PKcs also have an overlapping spectrum of substrates with ATM, including the key downstream target H2AX [36]. Therefore, DNAPKcs could contribute to DDR signaling in ATM-deficient or-inhibited conditions, playing critical roles of redundancy.

\section{Therapeutic Exploitation of DNA Damage Response}

\subsection{PARP Inhibitors}

The PARP family of proteins plays a key role in the DDR. Following SSBs, these proteins bind tightly to DNA breaks, recruit DNA repair effectors, and remodel the chromatin structure around the damaged DNA [37]. The antitumor activity of PARP inhibition is based on the concept of synthetic lethality. In cells with defects in HR, initially manifested in $B R C A 1$ or BRCA2 gene mutations, pharmacological inhibition of the compensatory DNA repair machinery leads to genomic instability, mitotic damage, and cell death [38-40]. PARP inhibitors block the catalytic activity by interacting with the binding site of nicotinamide adenine dinucleotide $\left(\mathrm{NAD}^{+}\right)$, a PARP cofactor, in the catalytic domains of PARP1 and PARP2. However, the antitumor mechanism of PARP inhibitors is not confined to impeding the catalytic activity of the enzyme; they also cause the 'trapping' of PARP in a complex with the DNA, which interferes with the catalytic cycle of PARP1 and damages the genomic integrity [41]. The various clinically developed PARP inhibitors have similar catalytic inhibitory effects against PARP, but they differ in their PARP-trapping abilities (talazoparib $>$ niraparib $>$ olaparib $=$ rucaparib $>$ veliparib), which also correlate with their cytotoxic potencies [37,41-43].

Apart from DSBs that are left unrepaired, with PARP inhibitors in BRCA-deficient tumor cells as the main mechanism for synthetic lethality, recent studies have suggested an alternative mechanism in which replication gaps in SSBs are critical for sensitivity to PARP inhibitors $[44,45]$. PARP1 and BRCA proteins are functionally crucial in recruiting repair proteins at SSBs, and recent work by Cong et al. has demonstrated that replicationassociated ssDNA gaps are the key factors that mediate the cytotoxicity of PARP inhibitors. While BRCA1- and FANCJ-deficient tumor cells are both defective in HR, only BRCA1deficient cells were sensitive to olaparib treatment, and this difference stemmed from distinct replication fork lengthening, which reflects replication-associated ssDNA gaps [44]. Additionally, replication gap suppression was shown to confer resistance to PARP inhibitors as ATR inhibition, which accelerates ssDNA gap induction, restored sensitivity to olaparib in a PARP inhibitor-resistant cell line [44]. This model has added an additional layer of scientific knowledge in predicting responses in non-BRCA mutant cancers and understanding the resistance mechanisms of PARP inhibitors. 
PARP inhibitors are the most extensively studied class of DDR inhibitors, and several PARP inhibitors have been approved for the treatment of ovarian and breast cancers by various regulatory officials, including the United States Food and Drug Administration and the European Medicines Agency. Currently, its treatment indications are expanding through various clinical investigations targeting beyond BRCA1/2 mutations and a broader range of malignancies [6].

\subsection{DDR Pathway Inhibitors beyond PARP Inhibitors}

DNA damage mostly occurs as SSBs, but DSBs are more detrimental to cells. Therefore, most DDR-targeted therapies have focused on altering the functions of repair machinery associated with DSBs or on inhibiting checkpoint molecules that act downstream of these repair processes.

\subsubsection{ATR Inhibitors}

Given its critical role in the DDR pathway, ATR inhibition is a promising target for anticancer therapy. In preclinical studies, genetic inactivation by induced expression of a dominant-negative ATR kinase-dead mutant led to enhanced sensitivity to various anticancer agents, which provided the rationale for developing pharmacologic inhibition strategies [46,47]. Furthermore, the progress in high-throughput screening methods for ATR activity has enabled the discovery of potent and selective ATR inhibitors.

VE-821 was one of the earliest selective inhibitors discovered via high-throughput screening of ATR activity; it showed the potent and more selective inhibition of ATR compared with the related kinases, ATM and DNA-PK [48]. It was optimized and modified to produce VE-822 and VX-970 with enhanced affinity to ATR and improved solubility, suitable for in vivo studies [49,50]. VX-970, also known as M6620 or berzosertib, is a first-in-class drug and has been studied as monotherapy or in combination with cytotoxic chemotherapeutic agents (topotecan, carboplatin, cisplatin, gemcitabine) in phase 1 clinical trials, which demonstrated its safety and clinical benefits (Table 1) [51-54]. These results led to further studies that tested berzosertib in combination with cytotoxic chemotherapy. In a randomized phase 2 trial for the treatment of platinum-resistant ovarian cancer, berzosertib combined with gemcitabine was associated with significantly prolonged progression-free survival (PFS) compared with gemcitabine alone (22.9 weeks vs. 14.7 weeks) [55]. Despite these promising results, clinical trials with negative results have also been reported. In a phase 2 trial for urothelial carcinoma therapy, berzosertib was added to gemcitabine and cisplatin as first-line treatment and compared with chemotherapy alone; PFS was not significantly different between the berzosertib group vs. chemotherapy alone (8.0 months for both arms), but overall survival (OS) was shorter in the berzosertib group (14.4 months vs. 19.8 months). The combination arm also had higher rates of serious adverse events, which were mostly related to myelosuppression [56]. Although the results of ongoing studies are anticipated, these phase 2 trial results imply that combination strategies should be optimized for the selection of partner drugs and target patients (Table 1).

AZD6738 (ceralasertib) was also developed using strategies stemming from highthroughput screening data. The initially discovered compound was AZ20, which inhibits ATR, with low $\mathrm{IC}_{50}$ values in various cell lines [57]. Nevertheless, its low aqueous solubility and weak inhibition of CYP3A4 are major hurdles for this drug to progress to clinical trials. However, chemical modifications that improve solubility and eliminate CYP3A4 inhibitory activity have facilitated the successful development of AZD6738 (ceralasertib), which is suitable for clinical studies [58]. Based on preclinical studies showing the antitumor activity of ceralasertib in combination with DNA-damaging anticancer agents, phase 1 trials were conducted on ceralasertib in combination with cytotoxic chemotherapeutic agents (Table 1). In a trial combining ceralasertib with paclitaxel, 57 patients with advanced solid tumors displayed good treatment tolerance, with dose escalation starting from $40 \mathrm{mg}$ daily up to $240 \mathrm{mg}$ twice daily (480 mg per day) on a 14-day schedule for each cycle. Encouraging antitumor activity was noted among patients with melanoma in the early cohorts, while 
enhanced effects were observed in later cohorts in patients with melanoma refractory to anti-cell death protein 1 (PD-1) and anti-programmed death-ligand 1 (PD-L1) treatments, evidenced by an overall response rate of $33.3 \%(n=33)$ [59]. In another phase 1 trial, ceralasertib was combined with carboplatin under various dosage schedules. The starting dose of ceralasertib was $20 \mathrm{mg}$ twice daily on a 17-day schedule but was later amended to shorten the treatment period to 10 days, then to 7 , and finally to 2 days, as the participants were deemed intolerant to the treatment [60]. The maximum tolerated dose (MTD) was $40 \mathrm{mg}$ once daily on days 1-2 with carboplatin (AUC 5) every 3 weeks. Among the 36 patients enrolled in this trial, two showed partial responses [60]. These two phase 1 trials, combining ceralasertib with different cytotoxic agents, suggested that ATR inhibitors may have appropriate partner drugs that could be combined to improve tolerability and antitumor efficacy. Further studies are ongoing, and the results are anticipated for the development of better combinatorial strategies.

BAY 1895344 is another oral selective and potent ATR inhibitor discovered and optimized for in vivo studies using the high-throughput screening of chemical compounds [61]. Preclinical studies of this drug as monotherapy in DDR deficiencies revealed promising antitumor activity as well as synergistic activity in combination with DNA damage-inducing chemotherapy or radiotherapy [62]. In a phase 1 trial, 22 patients with advanced solid tumors or non-Hodgkin lymphoma refractory to standard treatments were enrolled (Table 1). BAY 1895344 was started at 5 to $80 \mathrm{mg}$ twice daily, and the MTD was determined as $40 \mathrm{mg}$ twice daily on a 3-days-on/4-days-off schedule. Among the 20 patients evaluable for tumor response, 4 achieved partial responses [63]. Interestingly, all four patients with partial responses had deleterious ATM mutations identified via targeted DNA sequencing or loss of protein expression based on immunohistochemistry [63]. As BAY 1995344 has shown promising antitumor activity as a single-agent therapy, further studies in combination with a PARP inhibitor (niraparib) or an immune checkpoint inhibitor (pembrolizumab) are underway (NCT04267939; NCT04095273).

M4344 is an oral ATR inhibitor that is currently undergoing clinical studies. Preclinical data have shown its anticancer activity as monotherapy and its synergism with cytotoxic agents in organoid and xenograft models [64]. Currently, M4344 is undergoing phase 1 trials as a single agent and combined with carboplatin in advanced solid tumors (NCT02278250) and is also under preparation for trials in combination with niraparib for recurrent ovarian cancer therapy (NCT04149145).

Table 1. Clinical trials of ATR inhibitors.

\begin{tabular}{|c|c|c|c|c|c|}
\hline $\begin{array}{l}\text { Trial } \\
\text { Phase }\end{array}$ & $\begin{array}{l}\text { Disease } \\
\text { Setting }\end{array}$ & Treatments & $\begin{array}{c}\text { Most Common } \\
\text { Grade } \geq 3 \text { Toxicity }\end{array}$ & Efficacy & Reference \\
\hline \multicolumn{6}{|c|}{ Berzosertib/M6620/VX-970 } \\
\hline 1 & Solid tumors & $\begin{array}{c}\text { Escalating doses of } \\
\text { M6620 } \\
\text { with topotecan }\end{array}$ & $\begin{array}{c}\text { Anemia }(19 \%), \\
\text { Leukopenia }(19 \%), \\
\text { Neutropenia }(19 \%)\end{array}$ & $\begin{array}{l}\text { PR 2/21 (10\%) } \\
\text { SD 7/21 (33\%) }\end{array}$ & [51] \\
\hline 1 & Solid tumors & $\begin{array}{c}\text { Escalating doses of } \\
\text { M6620, } \\
\text { or combination } \\
\text { with carboplatin }\end{array}$ & $\begin{array}{l}\text { Monotherapy: None } \\
\text { With carboplatin: } \\
\text { Neutropenia }(22 \%)\end{array}$ & $\begin{array}{c}\text { Monotherapy: } \\
\text { PR 1/17 (6\%) } \\
\text { SD 5/17 (29\%) } \\
\text { With carboplatin: } \\
\text { PR 1/21 (5\%) } \\
\text { SD 15/21 (71\%) }\end{array}$ & [52] \\
\hline 1 & Solid tumors & $\begin{array}{c}\text { Escalating doses of } \\
\text { berzosertib } \\
\text { with cisplatin }\end{array}$ & $\begin{array}{c}\text { Neutropenia }(20 \%), \\
\text { Anemia }(17 \%)\end{array}$ & $\begin{array}{c}\text { PR 4/26 (15\%) } \\
\text { SD 15/26 (58\%) }\end{array}$ & [53] \\
\hline
\end{tabular}


Table 1. Cont.

\begin{tabular}{|c|c|c|c|c|c|}
\hline $\begin{array}{l}\text { Trial } \\
\text { Phase }\end{array}$ & $\begin{array}{l}\text { Disease } \\
\text { Setting }\end{array}$ & Treatments & $\begin{array}{l}\text { Most Common } \\
\text { Grade } \geq 3 \text { Toxicity }\end{array}$ & Efficacy & Reference \\
\hline 1 & Solid tumors & $\begin{array}{l}\text { Escalating doses of } \\
\text { berzosertib with } \\
\text { gemcitabine }+/- \\
\text { cisplatin }\end{array}$ & $\begin{array}{c}\text { With gemcitabine } \\
\text { Neutropenia }(16 \%) \\
\text { ALT increased }(16 \%) \\
\text { Fatigue }(16 \%) \\
\text { With gemcitabine + } \\
\text { cisplatin } \\
\text { Neutropenia }(63 \%) \\
\text { Thrombocytopenia }(38 \%)\end{array}$ & $\begin{array}{c}\text { With gemcitabine } \\
\text { PR } 4 / 48(8 \%) \\
\text { SD } 29 / 48(60 \%) \\
\text { With gemcitabine + cisplatin } \\
\text { PR } 1 / 7(14 \%) \\
\text { SD } 4 / 7(57 \%)\end{array}$ & [54] \\
\hline 2 & $\begin{array}{l}\text { Ovarian cancer } \\
\text { (Platinum- } \\
\text { resistant) }\end{array}$ & $\begin{array}{c}\text { Randomization }(1: 1) \\
\text { Gemcitabine }+/- \\
\text { berzosertib }\end{array}$ & $\begin{array}{c}\text { Gemcitabine + berzosertib: } \\
\text { Neutropenia }(35 \%) \\
\text { Anemia }(15 \%) \\
\text { Gemcitabine alone: } \\
\text { Neutropenia }(28 \%) \\
\text { Anemia }(11 \%)\end{array}$ & $\begin{array}{c}\text { Gemcitabine }+ \text { berzosertib } \\
\text { PFS } 22.9 \text { weeks } \\
\text { Gemcitabine alone } \\
\text { PFS } 14.7 \text { weeks } \\
\text { (HR } 0.57,90 \% \text { CI } 0.33-0.98)\end{array}$ & [55] \\
\hline 2 & $\begin{array}{l}\text { Urothelial } \\
\text { carcinoma }\end{array}$ & $\begin{array}{l}\text { Randomization }(1: 1) \\
\text { Gemcitabine + Cisplatin } \\
+/- \text { berzosertib }\end{array}$ & $\begin{array}{c}\text { Gemcitabine + cisplatin + } \\
\text { berzosertib: } \\
\text { Anemia }(57 \%) \\
\text { Gemcitabine + cisplatin: } \\
\text { Anemia }(25 \%)\end{array}$ & $\begin{array}{c}\text { Gemcitabine + cisplatin }+ \\
\text { berzosertib: } \\
\text { PFS } 8.0 \text { months } \\
\text { OS } 14.4 \text { months } \\
\text { Gemcitabine + cisplatin: } \\
\text { PFS } 8.0 \text { months } \\
\text { OS } 19.8 \text { months } \\
\text { HR for PFS: } 1.22 \\
\text { (95\% CI 0.72-2.08) } \\
\text { HR for OS: } 1.42 \\
\text { (95\% CI } 0.76-2.68)\end{array}$ & [56] \\
\hline \multicolumn{6}{|c|}{ Ceralasertib/AZD6738 } \\
\hline 1 & Solid tumors & $\begin{array}{l}\text { Escalating doses of } \\
\text { berzosertib with } \\
\text { paclitaxel }\end{array}$ & $\begin{array}{l}\text { Neutropenia }(30 \%) \\
\text { Anemia }(23 \%)\end{array}$ & $\begin{array}{c}\text { CR } 1 / 57(2 \%) \\
\text { PR } 12 / 57(21 \%) \\
\text { SD } 18 / 57(32 \%)\end{array}$ & [59] \\
\hline 1 & Solid tumors & $\begin{array}{l}\text { Escalating doses of } \\
\text { berzosertib with } \\
\text { carboplatin }\end{array}$ & $\begin{array}{c}\text { Anemia }(39 \%) \\
\text { Thrombocytopenia }(36 \%) \\
\text { Neutropenia }(25 \%)\end{array}$ & $\begin{array}{c}\text { PR 2/34 (6\%) } \\
\text { SD } 18 / 34(53 \%)\end{array}$ & {$[60]$} \\
\hline 2 & Melanoma & $\begin{array}{l}\text { Ceralasertib + } \\
\text { Durvalumab }\end{array}$ & $\begin{array}{c}\text { Anemia }(33 \%) \\
\text { Thrombocytopenia }(23 \%)\end{array}$ & $\begin{array}{c}\text { PR 9/30 (30\%) } \\
\text { SD 10/30 (33\%) } \\
\text { Median PFS 7.1 months } \\
(95 \% \text { CI 3.6-10.6) } \\
\text { Median OS 14.2 months } \\
\text { (95\% CI 9.3-19.1) }\end{array}$ & [65] \\
\hline \multicolumn{6}{|c|}{ BAY-1895344 } \\
\hline 1 & Solid tumors & $\begin{array}{l}\text { Escalating doses of } \\
\text { BAY-1895344 }\end{array}$ & $\begin{array}{c}\text { Neutropenia }(55 \%) \\
\text { Leukopenia }(18 \%) \\
\text { Thrombocytopenia }(18 \%)\end{array}$ & $\begin{array}{l}\text { PR 4/21 (19\%) } \\
\text { SD 8/21 (38\%) }\end{array}$ & [63] \\
\hline \multicolumn{6}{|c|}{ M4344 } \\
\hline 1 & Solid tumors & $\begin{array}{l}\text { Escalating doses of } \\
\text { M4344 } \\
\text { or combination with } \\
\text { carboplatin }\end{array}$ & $\begin{array}{l}\text { Trial ongoing } \\
\text { (Not reported) }\end{array}$ & $\begin{array}{l}\text { Trial ongoing } \\
\text { (Not reported) }\end{array}$ & $\begin{array}{c}\text { NCT } \\
02278250\end{array}$ \\
\hline
\end{tabular}

PR, partial response; SD, stable disease; PFS, progression-free survival; OS, overall survival.

\subsubsection{ATM Inhibitors}

ATM is a master regulator of DSB repair and has been extensively explored as a therapeutic target for anticancer therapy. Preclinical studies have shown that inhibiting 
ATM kinase activity sensitizes cells to ionizing radiation [66]. The potent KU-55933, which was the first selective ATM inhibitor, induced significant sensitization to radiation and DNA-damaging chemotherapeutic agents, including etoposide, doxorubicin, and camptothecin [67]. Due to its high lipophilicity and low bioavailability, it was later optimized to KU-60019, with improved aqueous solubility [68]. However, the low bioavailability of these drugs makes them unsuitable for clinical studies.

AZD0156 is a recently developed ATM inhibitor with high oral bioavailability [69]. Although AZD0156 alone was not effective in inhibiting the growth of cancer cells in a xenograft model of colon cancer (SW620) or patient-derived xenograft model of BRCA2mutant breast cancer, the combination of AZD0156 with irinotecan (colon cancer) or olaparib (breast cancer) was shown to result in synergistic inhibitory effects [69]. Based on these preliminary data, AZD0156 is undergoing a phase 1 trial in combination with olaparib or irinotecan (NCT02588105).

Stemming from a similar developmental series as AZD0156, AZD1390 also displays high selectivity and potency against ATM kinase activity, along with good pharmacokinetic and pharmacodynamic profiles [70]. Additionally, this drug has been shown to display excellent blood-brain barrier (BBB) permeability. In preclinical studies, AZD1390 was shown to radiosensitize orthotopic mouse models of glioblastoma and lung cancer with brain metastasis [70]; consequently, it is currently undergoing phase 1 clinical trials in combination with radiation therapies for brain tumors (NCT03423628) and lung cancer (NCT04550104).

M3541 is another recently developed oral ATM inhibitor [71]. Preclinical studies have shown that M3541 sensitizes human xenograft cancer models to ionizing radiation [71,72]. Thus, a phase 1 trial was conducted to test the antitumor activity of M3541 in combination with palliative radiotherapy (NCT03225105), but the results have yet to be published.

\subsubsection{DNA-PK Inhibitors}

DNA-PK plays a critical role in NHEJ-mediated DSB repair. Inhibition of this upstream regulator has been explored as an attractive target for radio- or chemosensitization as these modalities, which constitute the backbone of anticancer treatment, frequently induce DSBs [73]. Due to its structural similarity to DNA-PK, early developmental attempts largely focused on inhibitors targeting PI3K.

In line with this background, CC-115 was developed during the optimization of the triazole-containing mammalian target of rapamycin inhibitors, which were later shown to confer DNA-PK inhibitory activity as well [74,75]. The first report of CC-115 in human cancer therapy was in patients with relapsed/refractory chronic lymphocytic leukemia (CLL) harboring ATM deletions/mutations; clinical benefits were observed in 7 out of 8 patients (Table 2) [76]. In a more recent study, CC-115 was tested in the dose-finding and cohort expansion phases and was well-tolerated and showed preliminary efficacy [77]. Partial responses were observed in patients with CLL (31\%), and long-term disease stabilization was observed in patients with head and neck cancer, castration-resistant prostate cancer, and glioblastoma [77]. Ongoing studies of CC-115 for prostate cancer (NCT02833883) and glioblastoma (NCT02977780) are expected to provide additional insights into the clinical efficacy of this novel agent.

M3814 (nedisertib, or peposertib) is a selective and potent inhibitor of DNA-PK that has been shown to sensitize tumors to ionizing radiation and synergize with topoisomerase inhibitors in preclinical studies [78-80]. In the phase 1 trial, 31 patients with treatmentrefractory solid tumors were enrolled in dose-escalation cohorts and administered M3814 as monotherapy, which displayed good tolerability and modest efficacy (stable disease was achieved in 12 out of 31 patients) [81]. Based on preclinical evidence demonstrating the synergistic antitumor efficacy of M3814 combined with ionizing radiation, numerous ongoing studies have investigated this treatment combination in rectal cancer (NCT03770689), glioblastoma and gliosarcoma (NCT04555577), prostate cancer (NCT04071236), pancreatic cancer (NCT04172532), head and neck cancer (NCT04533750), and neuroendocrine tumors 
(NCT04750954). It has also been tested in combination with pegylated liposomal doxorubicin in ovarian cancer (NCT04092270) and with avelumab plus radiation (NCT04068194, NCT03724890) in various solid tumors.

AZD7648 is also a selective DNA-PK inhibitor that was screened and optimized among various chemical compounds developed by AstraZeneca [82,83]. Preclinical experiments have shown that AZD7648 enhances sensitivity to ionizing radiation and doxorubicin and synergizes with the PARP inhibitor, olaparib [82]. Based on these data, AZD7648 is undergoing a phase $1 / 2$ trial that includes a monotherapy arm for dose-finding and a combination arm with pegylated liposomal doxorubicin (NCT03907969).

Table 2. Clinical trials of DNA-PK inhibitors.

\begin{tabular}{|c|c|c|c|c|c|}
\hline $\begin{array}{l}\text { Trial } \\
\text { Phase }\end{array}$ & $\begin{array}{l}\text { Disease } \\
\text { Setting }\end{array}$ & Treatments & $\begin{array}{c}\text { Most Common } \\
\text { Grade } \geq 3 \text { Toxicity }\end{array}$ & Efficacy & Reference \\
\hline \multicolumn{6}{|c|}{ CC-115 } \\
\hline 1 & $\begin{array}{c}\text { Refractory/relapsed } \\
\text { CLL/SLL }\end{array}$ & $\begin{array}{l}\text { CC-115 } \\
\text { monotherapy }\end{array}$ & Not reported & $\begin{array}{c}\text { PR 4/8 (50\%) } \\
1 \text { PR with IWCLL criteria } \\
3 \text { PR with lymphocytosis } \\
\text { SD 3/8 }(38 \%)\end{array}$ & [76] \\
\hline 1 & $\begin{array}{c}\text { Cohort A } \\
\text { (dose-escalation): solid } \\
\text { tumors } \\
\text { Cohort B } \\
\text { (dose-expansion): } \\
\text { selected refractory } \\
\text { solid tumors }\end{array}$ & $\begin{array}{l}\text { CC-115 } \\
\text { monotherapy }\end{array}$ & $\begin{array}{l}\text { Cohort A: } \\
\text { Patients with at least one } \\
\text { related Gr } 3 \text { AE }(41 \%) \\
\text { Cohort B: } \\
\text { Patients with at least one } \\
\text { related Gr } 3 \text { AE }(26 \%)\end{array}$ & $\begin{array}{c}\text { Cohort A: } \\
\text { CR 1/39 (3\%) } \\
\text { PR 1/39 (3\%) } \\
\text { SD 18/39 (46\%) } \\
\text { Cohort B: } \\
\text {-CLL/SLL } \\
\text { PR 5/16 (31\%) } \\
\text { SD 4/16 (25\%) } \\
\text {-Overall } \\
\text { PR 7/78 (9\%) } \\
\text { SD 29/78 (37\%) }\end{array}$ & [77] \\
\hline \multicolumn{6}{|c|}{ M3814/Nedisertib/Peposertib } \\
\hline 1 & Solid tumors & $\begin{array}{l}\text { Escalating doses of } \\
\text { peposertib }\end{array}$ & $\begin{array}{c}\text { Maculo-papular rash } \\
\qquad(13 \%) \\
\text { Nausea }(7 \%)\end{array}$ & SD 12/31 (39\%) & [81] \\
\hline \multicolumn{6}{|c|}{ AZD7648 } \\
\hline $1 / 2$ & Solid tumors & $\begin{array}{l}\text { AZD7648 alone or } \\
\text { in combination } \\
\text { with pegylated } \\
\text { liposomal } \\
\text { doxorubicin }\end{array}$ & $\begin{array}{l}\text { Trial ongoing } \\
\text { (Not reported) }\end{array}$ & $\begin{array}{l}\text { Trial ongoing } \\
\text { (Not reported) }\end{array}$ & $\begin{array}{c}\text { NCT } \\
03907969\end{array}$ \\
\hline
\end{tabular}

PR, partial response; SD, stable disease.

\subsubsection{CHK1/2 Inhibitors}

CHK1 and CHK2 are the downstream targets of ATR and ATM, which are required for cell cycle arrest and DNA damage repair. Inhibition of these kinases results in premature entry into mitosis and accumulation of DNA damage, eventually causing cell death. Numerous inhibitors have been developed for this strategy. However, drugs including UCN-01 [84,85], AZD7762 [86,87], LY2603618 [88,89], MK-8776 [90], and GDC-0575 [91], have shown low or modest antitumor efficacy, precluding further clinical development.

Prexasertib (LY2606368) is a CHK1 inhibitor that induces mitotic catastrophe and shows promising antitumor effects in preclinical models [92]. In phase 1 trials, treatment with prexasertib caused a high frequency of grade 4 neutropenia, ranging from $50 \%$ to $73 \%$, although the effects were transient and reversible (Table 3) [93,94]. Phase 2 studies have been conducted in high-grade serous ovarian cancer [95], triple-negative breast cancer (TNBC) [96], and small cell lung cancer (SCLC) [97]. Although the efficacy was low for 
SCLC and modest for TNBC, prexasertib showed promising efficacy in ovarian cancer. In the phase 2 trial, 28 patients with $B R C A$-wild, recurrent high-grade serous ovarian cancer (enriched population with TP53 mutation) were enrolled, and 8 out of 24 patients with evaluable lesions showed partial responses [95]. Grade 4 neutropenia was also very common $(79 \%)$ but was mostly transient, with a median duration of 6 days, and resolved without growth-factor support [95]. Recent studies have also tested the combination of prexasertib with standard chemotherapy [98], olaparib [99], or anti-PD-L1 antibody [100]. In the olaparib-prexasertib combination study, 29 patients were enrolled, 18 of whom had BRCA1-mutant high-grade serous ovarian cancer resistant to prior PARP inhibitors. However, prexasertib and olaparib resulted in partial responses in four patients $(22 \%)$ and disease stabilization in six additional patients. Further studies of prexasertib are underway, both as monotherapy in TNBC (NCT04032080) and as combination therapy with cytotoxic agents, in small round cell tumor/rhabdomyosarcoma (NCT04095221) and brain tumors (NCT04023669).

Table 3. Clinical trials of $\mathrm{CHK} 1 / 2$ inhibitors.

\begin{tabular}{|c|c|c|c|c|c|}
\hline $\begin{array}{l}\text { Trial } \\
\text { Phase }\end{array}$ & $\begin{array}{l}\text { Disease } \\
\text { Setting }\end{array}$ & Treatments & $\begin{array}{c}\text { Most Common } \\
\text { Grade } \geq 3 \text { Toxicity }\end{array}$ & Efficacy & Reference \\
\hline \multicolumn{6}{|c|}{ Prexasertib/LY2606368 } \\
\hline 1 & Solid tumors & $\begin{array}{l}\text { Escalating doses of } \\
\text { LY2606368 }\end{array}$ & $\begin{array}{l}\text { Neutropenia }(89 \%) \\
\text { Leukopenia }(71 \%) \\
\text { Anemia }(69 \%)\end{array}$ & $\begin{array}{c}\text { PR } 2 / 45(4 \%) \\
\text { SD } 15 / 45(33 \%)\end{array}$ & [93] \\
\hline 1 & Solid tumors & $\begin{array}{l}\text { Prexasertib } \\
\text { monotherapy }\end{array}$ & $\begin{array}{c}\text { Neutropenia }(83 \%) \\
\text { Leukopenia }(75 \%) \\
\text { Thrombocytopenia }(33 \%)\end{array}$ & SD 8/11 (73\%) & [94] \\
\hline 1 & Solid tumors & $\begin{array}{c}\text { Prexasertib in } \\
\text { combination with } \\
\text { standard chemotherapy }\end{array}$ & $\begin{array}{c}\text { Prexasertib + Cisplatin } \\
\text { Neutropenia }(67 \%) \\
\text { Prexasertib + Cetuximab } \\
\text { Neutropenia }(54 \%) \\
\text { Prexasertib + 5-FU } \\
\text { Neutropenia }(100 \%)\end{array}$ & $\begin{array}{c}\text { Prexasertib + Cisplatin } \\
\text { PR 8/63 (13\%) } \\
\text { Prexasertib + Cetuximab } \\
\text { PR 7/31 (5\%) } \\
\text { Prexasertib + 5-FU } \\
\text { PR 1/8 (13\%) }\end{array}$ & [98] \\
\hline 1 & Solid tumors & $\begin{array}{l}\text { Prexasertib in } \\
\text { combination with } \\
\text { olaparib }\end{array}$ & Neutropenia (79\%) & $\begin{array}{c}\text { BRCA-mutant HGSOC } \\
\text { PR 4/18 (22\%) } \\
\text { SD 6/18 (33\%) }\end{array}$ & [99] \\
\hline 1 & Solid tumors & $\begin{array}{c}\text { Prexasertib in } \\
\text { combination with } \\
\text { LY3300054 (anti-PDL1 } \\
\text { antibody) }\end{array}$ & $\begin{array}{l}\text { Neutropenia }(82 \%) \\
\text { Leukopenia }(76 \%)\end{array}$ & $\begin{array}{l}\text { PR 3/17 (18\%) } \\
\text { SD 8/17 (47\%) }\end{array}$ & [100] \\
\hline 2 & $\begin{array}{c}\text { HGSOC } \\
\text { (BRCA-wild type) }\end{array}$ & $\begin{array}{l}\text { Prexasertib } \\
\text { monotherapy }\end{array}$ & $\begin{array}{l}\text { Neutropenia }(93 \%) \\
\text { Leukopenia }(82 \%)\end{array}$ & $\begin{array}{c}\text { PR } 8 / 28(29 \%) \\
\text { Median PFS } 7.4 \text { months } \\
(95 \% \text { CI } 2.1-9.4)\end{array}$ & [95] \\
\hline 2 & $\begin{array}{c}\text { TNBC } \\
\text { (BRCA-wild type) }\end{array}$ & $\begin{array}{l}\text { Prexasertib } \\
\text { monotherapy }\end{array}$ & $\begin{array}{c}\text { Neutropenia }(89 \%) \\
\text { Anemia }(33 \%)\end{array}$ & $\begin{array}{l}\text { PR 1/9 (11\%) } \\
\text { SD 4/9 (44\%) }\end{array}$ & [96] \\
\hline 2 & $\begin{array}{l}\text { Small-cell } \\
\text { lung cancer }\end{array}$ & $\begin{array}{l}\text { Prexasertib } \\
\text { monotherapy }\end{array}$ & Neutropenia $(65 \%)$ & $\begin{array}{c}\text { Platinum-sensitive: } \\
\text { PR 3/58 (5\%) } \\
\text { SD 15/58 (26\%) } \\
\text { Platinum-refractory: } \\
\text { PR 0/60 (0\%) } \\
\text { SD } 12 / 60(20 \%)\end{array}$ & [97] \\
\hline
\end{tabular}

PR, partial response; SD, stable disease; HGSOC, high-grade serous ovarian cancer; TNBC, triple-negative breast cancer.

\subsubsection{WEE1 Inhibitors}

WEE1 is a kinase that negatively regulates the cell cycle by phosphorylating and inhibiting the activities of its substrates, CDK1 and CDK2 [101]. WEE1 stabilizes replication 
forks during the S-phase and activates the G2/M checkpoint, providing sufficient time for the DDR machinery to restore the error. Therefore, WEE1 inhibition drives cells into mitosis without proper DNA damage repair and increases replication stress, resulting in mitotic catastrophe [102].

Adavosertib (initially named MK-1775, then AZD1775 during development) was the first selective WEE1 inhibitor reported to have antitumor effects in p53-deficient cells in combination with DNA-damaging agents $[102,103]$. Furthermore, it is currently the only drug of this category that has been extensively studied in clinical trials (Table 5).

In a phase 1 trial of adavosertib administered as monotherapy to 25 patients with refractory solid tumors, partial responses were observed in 2 patients, both of whom harbored tumors with a BRCA1-mutation [104]. In another phase 1 trial, adavosertib was administered as monotherapy or in combination with gemcitabine, cisplatin, or carboplatin [105]. Of the 176 patients enrolled in this study, 17 patients achieved a partial response, while patients with the TP53-mutation $(n=19)$ showed a response rate of $21 \%$ compared with $12 \%$ of patients with wild-type TP53 $(n=33)$. However, $42 \%$ of patients treated with chemotherapy combinations had grade 3 or higher hematologic toxicities, which was the most common type of adverse event [105]. Based on these promising studies, further phase 1 studies have investigated the combination of certain anticancer agents in specific types of cancers. In locally advanced or unresectable pancreatic cancer, adavosertib was combined with gemcitabine and radiation therapy at various doses [106], and in locally advanced head and neck cancer, it was combined with concurrent chemoradiation therapy with cisplatin [107]. Both studies demonstrated good drug tolerability with encouraging clinical outcomes for this strategy, suggesting that further studies should be conducted on adavosertib in combination with chemotherapy and radiotherapy.

Adavosertib has been tested in various phase 2 trials targeting ovarian cancer [108-111], breast cancer [112], colon cancer [113], SCLC [114], uterine serous carcinoma [115], and in a basket trial based on DNA repair pathway mutations [116]. Promising antitumor effects were observed in patients with ovarian cancer and uterine serous carcinoma, but the results of studies in patients with colon cancer, breast cancer, and SCLC were discouraging.

In studies of ovarian cancer, adavosertib was investigated in both platinumresistant/refractory and platinum-sensitive conditions. In a single-arm phase 2 study, adavosertib was combined with carboplatin in TP53-mutated ovarian cancer refractory/resistant to platinum-based first-line treatment within three months, representing a patient population expected to have poor clinical outcomes. The response rate was $43 \%$, with encouraging antitumor activity evidenced by a median PFS of 5.3 months and an overall survival of 12.6 months [108]. Another phase 2 trial that tested adavosertib for treatment of platinum-resistant/refractory ovarian cancer was designed as a four-arm study, combining adavosertib with either gemcitabine, paclitaxel, carboplatin, or pegylated liposomal doxorubicin; promising response rates were observed, in particular for an intense treatment regimen with the adavosertib-carboplatin combination (response rate of 66.7\%), but at the cost of significant toxicity [111]. Recently, a double-blinded, randomized phase 2 trial demonstrated that combining adavosertib with gemcitabine resulted in significantly longer PFS and OS compared to gemcitabine alone in platinum-refractory/resistant ovarian cancer, enriched with TP53 mutations [110]. In a single-arm phase 2 trial for uterine serous carcinoma after failure of first-line platinum-based treatment, adavosertib was administered as monotherapy with a response rate of $29.4 \%$ and a 6 -month PFS rate of $47.1 \%$, which met the primary endpoint of the study [115]. Overall, these results imply that adavosertib holds great potential as monotherapy or in combination with DNA-damaging agents, and the outcomes of ongoing studies are anticipated to broaden our clinical and mechanistic insights into WEE1 inhibition in various types of cancers. 
Table 4. Clinical trials of WEE1 inhibitors.

\begin{tabular}{|c|c|c|c|c|c|}
\hline $\begin{array}{l}\text { Trial } \\
\text { Phase }\end{array}$ & $\begin{array}{l}\text { Disease } \\
\text { Setting }\end{array}$ & Treatments & $\begin{array}{l}\text { Most Common } \\
\text { Grade } \geq 3 \text { Toxicity }\end{array}$ & Efficacy & Reference \\
\hline \multicolumn{6}{|c|}{ Adavosertib/MK-1775/AZD1775 } \\
\hline 1 & Solid tumors & $\begin{array}{l}\text { Escalating doses of } \\
\text { AZD1775 }\end{array}$ & $\begin{array}{l}\text { Lymphopenia }(20 \%) \\
\text { Neutropenia }(16 \%) \\
\text { Anemia }(16 \%)\end{array}$ & PR 2/25 (8\%) & [104] \\
\hline 1 & Solid tumors & $\begin{array}{l}\text { AZD1775 alone or in } \\
\text { combination with } \\
\text { standard chemotherapy }\end{array}$ & $\begin{array}{l}\text { AZD1775 + Gemcitabine: } \\
\text { Neutropenia (33\%) } \\
\text { AZD1775 + Cisplatin: } \\
\text { Neutropenia }(12 \%) \\
\text { AZD1775 + Carboplatiin: } \\
\text { Thrombocytopenia }(31 \%) \\
\text { Neutropenia }(18 \%)\end{array}$ & $\begin{array}{c}\text { AZD1775 + Gemcitabine: } \\
\text { PR 4/81 (5\%) } \\
\text { AZD1775 + Cisplatin: } \\
\text { PR 9/58 (16\%) } \\
\text { AZD1775 + Carboplatiin: } \\
\text { PR 4/62 (6\%) }\end{array}$ & [105] \\
\hline 1 & $\begin{array}{l}\text { Locally advanced } \\
\text { pancreatic cancer }\end{array}$ & $\begin{array}{l}\text { Escalating doses of } \\
\text { AZD1775 with } \\
\text { gemcitabine and } \\
\text { radiation }\end{array}$ & $\begin{array}{l}\text { Neutropenia }(12 \%) \\
\text { Fatigue }(9 \%) \\
\text { Fever }(9 \%) \\
\text { Anorexia/Nausea/ } \\
\text { Vomiting }(9 \%)\end{array}$ & $\begin{array}{l}\text { Median OS } 21.7 \text { months } \\
(90 \% \text { CI } 16.7-24.8) \\
\text { Median PFS 9.4 months } \\
(90 \% \text { CI 8.0-9.9) }\end{array}$ & [106] \\
\hline 1 & $\begin{array}{l}\text { Locally advanced } \\
\text { head and neck } \\
\text { cancer }\end{array}$ & $\begin{array}{l}\text { Escalating doses of } \\
\text { AZD1775 in } \\
\text { combination with } \\
\text { radiation }\end{array}$ & Lymphopenia (92\%) & $\begin{array}{l}\text { CR 8/10 (80\%) } \\
\text { PR 2/10 (20\%) }\end{array}$ & [107] \\
\hline 2 & $\begin{array}{l}\text { TP53-mutated } \\
\text { refractory ovarian } \\
\text { cancer }\end{array}$ & $\begin{array}{l}\text { AZD1775 in } \\
\text { combination with } \\
\text { carboplatin }\end{array}$ & $\begin{array}{c}\text { Thrombocytopenia }(48 \%) \\
\text { Neutropenia }(39 \%)\end{array}$ & $\begin{array}{l}\text { CR 1/21 (5\%) } \\
\text { PR 8/21 (38\%) } \\
\text { SD 7/21 (33\%) }\end{array}$ & [108] \\
\hline 2 & $\begin{array}{l}\text { TP53-mutated, } \\
\text { platinum-sensitive } \\
\text { ovarian cancer }\end{array}$ & $\begin{array}{l}\text { Randomization (1:1) } \\
\text { Paclitaxel and } \\
\text { Carboplatin +/- } \\
\text { AZD1775 }\end{array}$ & $\begin{array}{c}\text { AZD1775 + } \\
\text { Chemotherapy: } \\
\text { Neutropenia }(36 \%) \\
\text { Placebo + Chemotherapy: } \\
\text { Neutropenia }(33 \%)\end{array}$ & $\begin{array}{l}\text { AZD1775 + Chemotherapy: } \\
\text { PFS } 7.9 \text { months } \\
\text { Placebo + Chemotherapy: } \\
\text { PFS } 7.3 \text { months } \\
\text { HR for PFS: } 0.63 \\
(95 \% \text { CI } 0.38-1.06)\end{array}$ & [109] \\
\hline 2 & $\begin{array}{l}\text { Platinum- } \\
\text { refractory ovarian } \\
\text { cancer }\end{array}$ & $\begin{array}{c}\text { Randomization (2:1) } \\
\text { Gemcitabine +/- } \\
\text { Adavosertib }\end{array}$ & $\begin{array}{c}\text { AZD1775 + Gemcitabine: } \\
\text { Neutropenia }(62 \%) \\
\text { Placebo + Gemcitabine } \\
\text { Neutropenia }(30 \%)\end{array}$ & $\begin{array}{l}\text { AZD1775 + Gemcitabine: } \\
\text { PFS } 4.6 \text { months } \\
\text { Placebo + Gemcitabine: } \\
\text { PFS } 3.0 \text { months } \\
\text { HR for PFS: } 0.55 \\
(95 \% \text { CI } 0.35-0.90)\end{array}$ & [110] \\
\hline 2 & $\begin{array}{l}\text { Platinum-resistant } \\
\text { ovarian cancer }\end{array}$ & $\begin{array}{c}\text { Adavosertib in } \\
\text { combination with } \\
\text { - Gemcitabine } \\
\text { - Paclitaxel } \\
\text { - Carboplatin } \\
\text { - Pegylated liposomal } \\
\text { doxorubicin (PLD) }\end{array}$ & $\begin{array}{c}\text { with Gemcitabine } \\
\text { Neutropenia }(78 \%) \\
\text { with Paclitaxel } \\
\text { Neutropenia }(53 \%) \\
\text { with Carboplatin } \\
\text { Thrombocytopenia }(63 \%) \\
\text { with PLD } \\
\text { Neutropenia }(17 \%)\end{array}$ & $\begin{array}{l}\text { with Gemcitabine } \\
\text { PR 1/9 (11\%) } \\
\text { with Paclitaxel } \\
\text { PR 10/38 (26\%) } \\
\text { with Carboplatin } \\
\text { PR 13/35 (37\%) } \\
\text { with PLD } \\
\text { PR 3/12 (25\%) }\end{array}$ & [111] \\
\hline 2 & TNBC & $\begin{array}{l}\text { Adavosertib in } \\
\text { combination with } \\
\text { cisplatin }\end{array}$ & $\begin{array}{c}\text { Diarrhea }(21 \%) \\
\text { Neutropenia }(18 \%)\end{array}$ & $\begin{array}{c}\text { CR 3/34 (9\%) } \\
\text { PR 6/34 (18\%) } \\
\text { SD 13/34 (38\%) }\end{array}$ & [112] \\
\hline
\end{tabular}


Table 5. Clinical trials of WEE1 inhibitors.

\begin{tabular}{|c|c|c|c|c|c|}
\hline $\begin{array}{l}\text { Trial } \\
\text { Phase }\end{array}$ & $\begin{array}{l}\text { Disease } \\
\text { Setting }\end{array}$ & Treatments & $\begin{array}{c}\text { Most Common } \\
\text { Grade } \geq 3 \text { Toxicity }\end{array}$ & Efficacy & Reference \\
\hline 2 & $\begin{array}{l}\text { Colorectal cancer } \\
\text { with TP53 and } \\
\text { RAS mutations }\end{array}$ & $\begin{array}{l}\text { Randomization (2:1) } \\
\text { (maintenance) } \\
\text { Adavosertib or active } \\
\text { monitoring }\end{array}$ & $\begin{array}{l}\text { Adavosertib } \\
\text { Diarrhea }(9 \%)\end{array}$ & $\begin{array}{l}\text { Adavosertib } \\
\text { PFS } 3.6 \text { months } \\
\text { OS } 14.0 \text { months } \\
\text { Active monitoring } \\
\text { PFS } 1.9 \text { months } \\
\text { OS } 12.8 \text { months } \\
\text { HR for PFS: } 0.35 \\
\text { (95\% CI } 0.18-0.68) \\
\text { HR for OS: } 0.92 \\
\text { (95\% CI } 0.44-1.94)\end{array}$ & [113] \\
\hline 2 & $\begin{array}{l}\text { Small cell lung } \\
\text { cancer }\end{array}$ & $\begin{array}{c}\text { Adavosertib } \\
\text { monotherapy } \\
\text { (biomarker-selected } \\
\text { patients) }\end{array}$ & Diarrhea 1/31 (3\%) & $\begin{array}{l}\text { PR 0/31 (0\%) } \\
\text { SD 9/31 (29\%) }\end{array}$ & [114] \\
\hline 2 & $\begin{array}{c}\text { Uterine serous } \\
\text { sarcoma }\end{array}$ & $\begin{array}{l}\text { Adavosertib } \\
\text { monotherapy }\end{array}$ & Neutropenia (32\%) & $\begin{array}{l}\text { CR 1/34 (3\%) } \\
\text { PR 9/34 (26\%) }\end{array}$ & [115] \\
\hline 2 & $\begin{array}{l}\text { Solid tumor with } \\
\text { mutations in DNA } \\
\text { repair genes }\end{array}$ & $\begin{array}{l}\text { Adavosertib in } \\
\text { combination with } \\
\text { carboplatin }\end{array}$ & $\begin{array}{c}\text { Anemia }(39 \%) \\
\text { Thrombocytopenia }(39 \%) \\
\text { Neutropenia }(32 \%)\end{array}$ & PR 0/24 (0\%) & [116] \\
\hline
\end{tabular}

PR, partial response; SD, stable disease; TNBC, triple-negative breast cancer.

\subsubsection{PLK1 Inhibitors}

PLK1 is a kinase that has an important role in overriding the G2/M checkpoint after DNA repair to re-enter the cell cycle. Since its activation promotes the re-entry of the cell cycle, PLK1 has been implicated to be overexpressed in a variety of cancers and thus serves as a potential therapeutic target.

Volasertib (initially named BI 6727) is an ATP-competitive inhibitor of PLK1 that was developed by modifying the previously developed BI 2536 by Boeringer Ingelheim (Table 6) [117]. In a phase 1 trial, volasertib was administered as monotherapy to 65 patients with refractory solid tumors, with doses escalating from 12 to $450 \mathrm{mg}$ at a 3-week-interval schedule. Reversible hematologic toxicity was the main adverse event, which was mostly manageable. In terms of efficacy, partial response was shown in 3 patients, and stable disease in 26 patients $(n=65)$ [118]. In a single-arm phase 2 trial against urothelial cancer, volasertib monotherapy resulted in modest efficacy, with a median PFS of 1.4 months [119].

Volasertib was investigated in clinical trials against acute myeloid leukemia (AML) in both phase 2 and 3 trials. In a randomized phase 2 study, volasertib was tested in combination with low-dose cytarabine for AML patients unsuitable for induction chemotherapy. The primary endpoint was met as the rate of complete remission was superior with the volasertib combination ( $31 \%$ vs. $13 \%$ ), but this was at the expense of hematologic toxicities [120]. However, in a phase 3 trial, this combination turned out to be unsuccessful, as volasertib in combination with low-dose cytarabine did not bring significant prolongation of overall survival despite the higher rates of complete remission [121].

Volasertib was also studied in solid tumors. In a phase 2 trial for the second-line treatment of non-small cell lung cancer (NSCLC), patients were randomized to three arms to either volasertib, pemetrexed, or a combination of the two agents [122]. The median PFS was 1.4 months for volasertib monotherapy, 3.3 months for volasertib combined with pemetrexed, and 5.3 months for pemetrexed alone, showing that volasertib has a minor role in the treatment of NSCLC. In a phase 2 trial of platinum-resistant ovarian cancer, patients were randomly assigned 1:1 to either volasertib or the investigator's choice of non-platinum single-agent chemotherapy [123]. The 24-week disease control rate, which was the primary endpoint, was $30.6 \%$ for volasertib compared to $43.1 \%$ for chemotherapy. 
Together, these studies have shown that volasertib has limited antitumor efficacy in solid tumors against patient populations that are unselected for specific biomarkers.

Onvansertib (also known as PCM-075 or NMS-1286937) is an orally available selective ATP-competitive inhibitor of PLK1 (Table 6) [124]. In a phase 1 trial, onvansertib was administered to patients with advanced solid tumors in cohorts of escalating doses. Hematologic events, including neutropenia and thrombocytopenia, were the major dose-limiting toxicities, and the best responses were stable disease in 5 out of 16 evaluable patients [125]. In a phase $1 \mathrm{~b}$ trial, onvansertib was combined with either low-dose cytarabine or decitabine in patients with AML. Complete remission was observed in 5 out of 21 patients who were administered with the decitabine combination, which prompted further investigation in a phase 2 trial [126]. Currently, this drug is undergoing further clinical investigation in metastatic colorectal cancer with KRAS mutation (NCT03829410), pancreatic cancer (NCT04752696), and CRPC (NCT03414034).

Table 6. Clinical trials of PLK1 inhibitors.

\begin{tabular}{|c|c|c|c|c|c|}
\hline $\begin{array}{l}\text { Trial } \\
\text { Phase }\end{array}$ & $\begin{array}{l}\text { Disease } \\
\text { Setting }\end{array}$ & Treatments & $\begin{array}{l}\text { Most Common } \\
\text { Grade } \geq 3 \text { Toxicity }\end{array}$ & Efficacy & Reference \\
\hline \multicolumn{6}{|c|}{ Volasertib/BI 6727} \\
\hline 1 & Solid tumors & $\begin{array}{l}\text { Escalating doses of } \\
\text { Volasertib }\end{array}$ & $\begin{array}{c}\text { Neutropenia }(14 \%) \\
\text { Thrombocytopenia }(14 \%)\end{array}$ & $\begin{array}{c}\text { PR 3/65 (5\%) } \\
\text { SD 26/65 (40\%) }\end{array}$ & [118] \\
\hline 2 & Urothelial cancer & $\begin{array}{l}\text { Volasertib } 300 \mathrm{mg} \text { every } \\
3 \text { weeks }\end{array}$ & $\begin{array}{c}\text { Neutropenia }(28 \%) \\
\text { Thrombocytopenia }(20 \%)\end{array}$ & $\begin{array}{c}\text { PR 7/50 (14\%) } \\
\text { SD 13/50 (26\%) } \\
\text { Median PFS } 1.4 \text { months } \\
\text { (95\% CI 1.3-2.6) } \\
\text { Median OS } 8.5 \text { months } \\
(95 \% \text { CI 3.9-12.1) }\end{array}$ & [119] \\
\hline 2 & $\begin{array}{l}\text { AML ineligible for } \\
\text { induction } \\
\text { chemotherapy }\end{array}$ & $\begin{array}{l}\text { Randomization (1:1) } \\
\text { LDAC +/- Volasertib }\end{array}$ & $\begin{array}{c}\text { Volasertib + LDAC: } \\
\text { Febrile neutropenia }(55 \%) \\
\text { LDAC: } \\
\text { Febrile Neutropenia }(16 \%)\end{array}$ & $\begin{array}{c}\text { Volasertib + LDAC: } \\
\text { CR + CRi 6/45 (13\%) } \\
\text { LDAC: } \\
\text { CR + CRi 13/42 (31\%) }\end{array}$ & [120] \\
\hline 3 & $\begin{array}{l}\text { AML ineligible for } \\
\text { induction } \\
\text { chemotherapy }\end{array}$ & $\begin{array}{l}\text { Randomization }(2: 1) \\
\text { Low-dose cytarabine } \\
+/- \text { Volasertib }\end{array}$ & $\begin{array}{c}\text { Volasertib + LDAC: } \\
\text { Febrile neutropenia (59\%) } \\
\text { Thrombocytopenia (39\%) } \\
\text { Placebo + LDAC: } \\
\text { Thrombocytopenia (29\%) } \\
\text { Febrile Neutropenia }(28 \%)\end{array}$ & $\begin{array}{c}\text { Volasertib + LDAC: } \\
\text { CR + CRi 123/444 (28\%) } \\
\text { Median OS: 5.6 months } \\
\text { (95\% CI 4.5-6.8) } \\
\text { Placebo + LDAC: } \\
\text { CR + CRi 38/222 (17\%) } \\
\text { Median OS: } 4.8 \text { months } \\
\text { (95\% CI 3.8-6.4) } \\
\text { HR for OS: 0.97 } \\
\text { (95\% CI 0.8-1.2) }\end{array}$ & [121] \\
\hline 2 & $\begin{array}{l}\text { NSCLC, } \\
\text { second-line } \\
\text { treatment }\end{array}$ & $\begin{array}{l}\text { Randomization } \\
\text { - Volasertib } \\
\text { - Pemetrexed } \\
\text { - Volasertib + } \\
\text { Pemetrexed }\end{array}$ & $\begin{array}{c}\text { Volasertib } \\
\text { Neutropenia }(14 \%) \\
\text { Pemetrexed } \\
\text { Fatigue }(9 \%) \\
\text { Volasertib + Pemetrexed } \\
\text { Neutropenia }(11 \%)\end{array}$ & $\begin{array}{c}\text { Volasertib } \\
\text { Median PFS: } 1.4 \text { months } \\
\text { Pemetrexed } \\
\text { Median PFS: } 5.3 \text { months } \\
\text { Volasertib + Pemetrexed } \\
\text { Median PFS: } 3.3 \text { months }\end{array}$ & [122] \\
\hline 2 & $\begin{array}{l}\text { Platinum-resistant } \\
\text { ovarian cancer }\end{array}$ & $\begin{array}{c}\text { Randomization (1:1) } \\
\text { Volasertib vs. } \\
\text { Chemotherapy } \\
\text { (non-platinum) }\end{array}$ & $\begin{array}{c}\text { Volasertib } \\
\text { Neutropenia }(44 \%) \\
\text { Chemotherapy } \\
\text { Neutropenia }(6 \%)\end{array}$ & $\begin{array}{c}\text { Volasertib } \\
24 \text { week DCR: } 30.6 \% \\
\text { Chemotherapy } \\
24 \text { week DCR: } 43.1 \%\end{array}$ & [123] \\
\hline
\end{tabular}


Table 6. Cont.

\begin{tabular}{|c|c|c|c|c|c|}
\hline $\begin{array}{l}\text { Trial } \\
\text { Phase }\end{array}$ & $\begin{array}{l}\text { Disease } \\
\text { Setting }\end{array}$ & Treatments & $\begin{array}{c}\text { Most Common } \\
\text { Grade } \geq 3 \text { Toxicity }\end{array}$ & Efficacy & Reference \\
\hline \multicolumn{6}{|c|}{ Onvansertib/PCM-075/NMS-1286937 } \\
\hline 1 & Solid tumors & $\begin{array}{l}\text { Escalating doses of } \\
\text { NMS-1286937 }\end{array}$ & $\begin{array}{c}\text { Neutropenia }(16 \%) \\
\text { Thrombocytopenia }(16 \%)\end{array}$ & SD 5/16 (31\%) & [125] \\
\hline 1 & AML & $\begin{array}{l}\text { Escalating doses of } \\
\text { onvansertib with either } \\
\text { LDAC or decitabnie }\end{array}$ & $\begin{array}{c}\text { Anemia }(35 \%) \\
\text { Thrombocytopenia }(25 \%) \\
\text { Neutropenia }(25 \%)\end{array}$ & $\begin{array}{c}\text { Onvansertib + LDAC } \\
\text { CR + CRi 1/15 (7\%) } \\
\text { Onvansertib + Decitabine } \\
\text { CR + CRi 5/21 }(24 \%)\end{array}$ & [126] \\
\hline
\end{tabular}

$\mathrm{CR}$, complete remission; $\mathrm{CRi}$, complete remission with incomplete blood count recovery; PR, partial response SD, stable disease; LDAC, low-dose cytarabine; DCR, disease control rate; AML, acute myeloid leukemia; NSCLC, non-small cell lung cancer.

\section{Biomarkers for DDR-Targeted Therapies: Beyond BRCA1/2 Mutations}

Based on synthetic lethality, PARP inhibitors have shown impressive clinical responses, especially in patients with $B R C A 1$ or $B R C A 2$ gene mutations. However, patients without direct mutations in these genes but with defects in other DNA damage repair pathways are said to exhibit 'BRCAness', which may also indicate sensitivity to DDR-targeted therapies [127].

\subsection{Homologous Recombination Deficiency (HRD) Scores}

Given that cells with defects in HR are expected to display genomic instability, assays that detect these features would allow the identification of patients with BRCAness. To identify genomic 'scars' related to HR deficiency, previous studies quantified largescale genetic changes to analyze and predict the $B R C A$ gene mutation status. Loss of heterozygosity $(\mathrm{LOH})$ was found to be more frequent in tumors defective in $B R C A 1$ or $B R C A 2$, and the number of these regions was highly associated with $B R C A$ gene mutation status [128]. Large-scale transitions (LST), defined as chromosomal breaks between adjacent regions of at least $10 \mathrm{MB}$, were found to be an indicator of $B R C A 1 / 2$-inactivation status [129]. Telomeric allelic imbalance (TAI), which is the number of subchromosomal regions with allelic imbalance extending to the telomeric end of the chromosome, was inversely correlated with $B R C A 1 / 2$ expression [130]. Later, it was suggested that combining these factors by calculating the mean score of the three indices robustly predicted BRCA1/2 deficiency in breast cancer [131]. Consequently, commercial tests, validated in clinical trials, are available for the estimation of BRCAness; these include myChoice CDx (Myriad Genetics), which combines tumor BRCA gene mutation analysis and the genomic instability score (unweighted sum of LOH, LST, and TAI) [132], and FoundationOne CDx (Foundation Medicine), which evaluates the percentage of genomic regions with $\mathrm{LOH}$ determined via next-generation sequencing $[133,134]$. PARP inhibitors demonstrated clinical benefits in patients without $B R C A 1 / 2$ mutations but with high HRD scores, emphasizing its predictive role in identifying patients with BRCAness $[135,136]$. However, the clinical validity of these HRD score tests, especially the cutoff values upon which treatment decisions are based, are mainly assessed in terms of PARP inhibitor responses rather than in terms of its biological status or predictive role in other DDR-targeted therapies; therefore, further validation is required for its application in a broader range of drugs [135].

\subsection{Sequencing-Based Mutational Signatures}

Genomic mutational signatures reflect nucleotide alterations caused by specific patterns of DNA-damaging insults [3]. In a seminal study that comprehensively classified somatic point mutations and large-scale genomic alterations from 7042 cancers into 20 distinct mutational signatures, 'signature $3^{\prime}$ was highly associated with $B R C A 1 / 2$-inactivating mutations $[3,137]$. This assay requires whole-exome or whole-genome sequencing, which limits its widespread utility as a clinical biomarker. However, recent developments in 
computational tools have allowed the detection of this signature using targeted panel sequencing [138]. Using this new method, signature 3 was validated to predict therapeutic responses to combined PARP and PD-1 inhibitor therapy in ovarian cancer [139]. Nevertheless, further studies are required to determine whether the assessment of signature 3 could also predict therapeutic responses to other DDR-targeted agents.

\section{Combination Strategies of DDR-Targeted Therapies}

In early clinical studies of DDR-targeted agents, durable clinical benefits were not achieved with single-agent therapies. In addition, sensitivity to these agents is inherently dependent on the DDR signaling pathway of the tumor. Thus, their combination with DNA damage-inducing therapies, including radiation or cytotoxic agents, has been widely adopted to maximize clinical benefits, as mentioned in the previous sections. Furthermore, novel combination partners, including DDR inhibitors of different classes, targeted agents, and immune checkpoint inhibitors, have also been tested to maximize the benefits of DDR-targeted therapies.

\subsection{Combination with DDR Inhibitors}

Preclinical studies have shown that concurrent targeting of multiple critical components of the DDR pathway leads to synergism and overcomes resistance to single-agent DDR inhibitors. This strategy has been mostly aimed at overcoming acquired resistance to PARP inhibitors, for which the best-known resistance mechanisms include restoration of HR repair and stabilization of the replication fork [140]. In preclinical studies, combining inhibitors of the ATR/CHK1/WEE1 pathway with PARP inhibitors proved to be an effective strategy [141-143]. Consequently, various clinical trials are ongoing to investigate combinations of DDR-targeted agents (NCT02588105, NCT03462342, NCT04149145, NCT03057145, and NCT04197713). However, overlapping toxicities of these drugs, most notably bone marrow suppression, remains a major challenge in the optimization of dosage schedules for clinical application.

\subsection{Combination with Targeted Agents}

Previous reports have demonstrated that pro-oncogenic signaling pathways can regulate DDR and cell cycle checkpoints through various mechanisms. Here, we summarize the strategies of combining DDR inhibitors with drugs that target oncogenic signaling cascades to maximize the antitumor effects. Most of the combination strategies are based on the addition of targeted agents to PARP inhibitors, the most extensively studied class among these drugs.

\subsubsection{Antiangiogenic Agents}

Angiogenesis is a hallmark of cancer and essential for tumor growth and metastasis. Interestingly, the crosstalk between angiogenesis and DDR signaling was noted by observing that PARP inhibition leads to defects in angiogenesis and, conversely, that hypoxic tumor cells acquire HR defects, which lead to increased sensitivity to PARP inhibition $[144,145]$. These backgrounds justified clinical trials of anti-angiogenic agents and PARP inhibitors. Cediranib, a tyrosine kinase inhibitor of vascular endothelial growth factor receptor 1-3, has been investigated as a combination partner with olaparib, mainly in ovarian cancer. In a phase 2 trial, cediranib plus olaparib was compared to olaparib alone in platinum-sensitive, relapsed ovarian cancer and resulted in a significant increase of PFS (16.5 months vs. 8.2 months), including in germline BRCA-wild type/unknown patients [146]. In a randomized phase 2 trial for the treatment of platinum-sensitive recurrent ovarian cancer, the combination of niraparib with bevacizumab, a monoclonal antibody against VEGF-A, was associated with longer PFS compared with niraparib alone (11.9 months vs. 5.5 months) [147]. Based on these promising results, a phase 3 trial of olaparib plus cediranib in ovarian cancer is underway to validate the clinical benefits shown in early-phase studies [148]. However, the olaparib-cediranib combination showed 
discouraging results in a single-arm phase 2 trial in patients with pancreatic cancer without germline BRCA mutations, as no clinical responses were observed [149]. These data imply that appropriate patient and disease selection are important when applying these strategies in clinical settings.

\subsubsection{PI3K Inhibitors}

PI3K signaling pathway activation plays an essential role in DSB sensing, and thus, combining PI3K and DDR inhibitors has been suggested as a potentially effective therapeutic strategy [150]. In preclinical studies, the combination of NVP-BKM120 (a PI3K inhibitor) and olaparib led to synergistic antitumor effects in mouse models [151,152]. This was followed by a phase 1 trial in which BKM120 with olaparib displayed promising clinical benefits in patients with recurrent ovarian cancer or TNBC, but also significant dose-limiting toxicities [153]. Alpelisib, an $\alpha$-specific PI3K inhibitor, was also tested in combination with olaparib in a phase $1 \mathrm{~b}$ trial targeting germline $B R C A$-mutant recurrent ovarian or breast cancer. The combination was both tolerable and effective, especially in epithelial ovarian cancer $(N=28)$, with 10 patients $(36 \%)$ achieving a partial response and $50 \%$ showing stable disease [154]. In two phase 1 trials, the combination of olaparib with capivasertib, an AKT inhibitor, demonstrated tolerability and antitumor efficacy in both germline $B R C A 1 / 2$-mutant and wild-type disease $[155,156]$. Further studies are ongoing (NCT04729387, NCT03660826) to validate the combination of PI3K-AKT pathway inhibitors and PARP inhibitors in various clinical situations.

\subsubsection{Antiandrogen Therapies}

Androgen receptor (AR) signaling is the most important therapeutic target in prostate cancer, and emerging evidence suggests that $\mathrm{AR}$ also regulates a network of DNA repair genes $[157,158]$. In mouse models of prostate cancer, AR inhibition led to activation of the PARP pathway, and dual inhibition of AR and PARP led to synthetic lethality $[159,160]$. The combination of AR inhibition by enzalutamide (AR antagonist) and AZD7762 (CHK1/2 inhibitor) showed a synergistic effect in xenograft models of prostate cancer [161]. Based on these preclinical data, abiraterone was combined with olaparib or placebo in a randomized phase 2 trial in patients with metastatic castration-resistant prostate cancer (mCRPC); abiraterone plus olaparib was associated with a significant prolongation of PFS vs. abiraterone plus placebo (13.8 months vs. 8.2 months, respectively) [162]. Currently, a phase 3 trial to test this combination as first-line therapy in patients with $\mathrm{mCRPC}$ is underway to validate these findings in a larger population (NCT03732820).

\subsubsection{MAPK Pathway Inhibitors}

The mitogen-activated protein kinase (MAPK) pathway includes the Ras-Raf-MEKERK cascade, and its activity is altered in many types of solid malignancies. Interestingly, a study that attempted to uncover the resistance mechanisms of PARP inhibitors noted that PARP inhibitors led to upregulation of MAPK signaling, and conversely, trametinib (a MEK inhibitor) led to upregulation of DDR signaling [163]. In addition, the combination of talazoparib and trametinib showed synergistic antitumor effects in a subset of ovarian cancer cell lines [163]. Based on this preclinical evidence, the combination of selumetinib (MEK inhibitor) and olaparib is undergoing a phase 1 trial (NCT03162627).

\subsection{Combination with Immune Checkpoint Inhibitors}

Increased tumor mutational burden is a surrogate marker for response to immune checkpoint inhibitors (ICIs) [164,165]. Tumors with DDR defects have a higher amount of accumulated somatic mutations, which suggests that they may show an enhanced response to ICIs. This concept is supported by the higher response rates to anti-PD1/PD-L1 therapies in patients with advanced urothelial cancers marked by DDR deficiencies [166]. Thus, DDR inhibitors have been suggested as promising candidate partners of ICIs, and these drug 
combination strategies are undergoing clinical investigation in a wide array of disease statuses [167].

Multiple lines of evidence have demonstrated the background mechanisms of how DDR inhibitors may potentiate antitumor immunity induced by ICIs. A number of studies have validated that PARP inhibitor-mediated DNA damage enhances T-cell recruitment and infiltration by activating the stimulator of interferon genes (STING) signaling pathway [168-170]. Accumulated DNA damage may lead to cytosolic DNA leakage, which activates the STING pathway, an innate immune cascade that boosts type 1 interferon signaling [171]. In addition, DSBs induced by X-rays or PARP inhibitors have been suggested to upregulate PD-L1 expression, which is a widely adopted biomarker for predicting the response to anti-PD1/PD-L1 antibodies [172,173].

A series of clinical trials have investigated the safety and efficacy of combining PARP inhibitors and anti-PD1/PD-L1 antibodies in various types of malignancies. The MEDIOLA trial (NCT02734004) is a phase $1 / 2$ study investigating olaparib and durvalumab (anti-PDL1 antibody) in four different types of cancers: (1) germline BRCA-mutated metastatic breast cancer [174], (2) germline BRCA-mutated platinum-sensitive relapsed ovarian cancer [175], (3) relapsed gastric cancer [176], and (4) relapsed SCLC [177]; this combination was tolerable, with no unexpected adverse events or additive toxicities observed. In the germline $B R C A$ mutated breast cancer cohort, the 12-week disease control rate (DCR) was $80 \%$ (24 out of 30 patients), meeting the primary endpoint [174]. In the germline $B R C A$-mutated ovarian cancer cohort, the 28 -week DCR was $65.6 \%$ and the objective response rate (ORR) was $71.9 \%$ (23 out of 32 patients), including 7 patients who achieved complete remission [175]. However, the efficacy was not very promising in gastric cancer or SCLC cohorts, as the primary endpoints were not met $[176,177]$. Olaparib and durvalumab were also tested in an independent phase $1 / 2$ clinical trial targeting mCRPC [178]. The median PFS for all 17 patients was 16.1 months, and 9 patients had radiographic and/or prostate-specific antigen responses.

The TOPACIO trial (NCT02657889) is a phase $1 / 2$ clinical study investigating the combination of niraparib and pembrolizumab (anti-PD1 antibody) in recurrent platinumresistant ovarian cancer and metastatic TNBC $[179,180]$. This combination was tolerable, with no new safety signals reported for either cohort. In the ovarian cancer cohort, the ORR was 18\% (11 of 60 evaluable patients), and the DCR was 65\% (39 out of 60 patients) [179]. Notably, 79\% (49 out of 60 patients with ovarian cancer) did not harbor tumor BRCA1 or $B R C A 2(\mathrm{t} B R C A)$ mutations, and $53 \%$ had a negative HRD status based on the assay from Myriad Genetics, but the clinical benefits of this combination were apparent regardless of $\mathrm{t} B R C A$ mutation or HRD status. In the TNBC cohort, the ORR was $29 \%$ (13 out of 45 patients) and the DCR was $49 \%$ (22 out of 45 patients), which also demonstrated the clinical benefit in patients with wild-type $t B R C A$ [180].

Recently, ceralasertib (an ATR inhibitor) was combined with durvalumab in a phase 2 trial in patients with melanoma who had failed prior anti-PD1 therapy [65]. The ORR among evaluable patients was 30\% (9 out of 30 patients) and the DCR was $63.3 \%$ (19 out of 30 patients). The response to the treatment combination was independent of prior immune checkpoint inhibitor responses, and biomarker analyses revealed that tumors with immune-enriched microenvironments or alterations in the DDR pathway had better chances of deriving clinical benefit [65].

Other DDR inhibitors are also undergoing active clinical investigations in combination with immune checkpoint inhibitors. As these two classes of drugs may show synergistic effects by targeting different tumor vulnerabilities, future trial results are anticipated to provide a broader view of therapeutic options [181].

\section{Conclusions}

Defects in DNA repair are abundant in cancer cells, offering an opportunity to exploit these alterations for clinical benefit. Although the molecular mechanisms of DDR have been an active area of scientific research for several decades, there remains more to under- 
stand in order to exploit this pathway as a therapeutic target. Following the success of PARP inhibitors, especially in the treatment of BRCA-mutated breast and ovarian cancers, biomarker studies to enrich the potential responders are an active area of research. In addition, optimal combination strategies with DNA-damaging cytotoxic agents, radiation, targeted agents, or ICIs are expected to broaden the range of indications of DDR-targeting strategies. The basic, preclinical, and clinical data discussed here emphasize the rapid growth of scientific knowledge in this field. Furthermore, ongoing investigations are expected to provide a more comprehensive understanding of this pathway and enable the development of better therapeutic strategies in the future.

Author Contributions: W.C. contributed to the data collection and writing of the manuscript. E.S.L. conceived the structure of the article and supervised the writing, reviewing, and editing of the manuscript. All authors have read and agreed to the published version of the manuscript.

Funding: This work was supported by a National Research Foundation of Korea (NRF) grant funded by the Korean government (MSIT) (No. 2021R1F1A1062942 to W.C.).

Institutional Review Board Statement: Not applicable.

Informed Consent Statement: Not applicable.

Data Availability Statement: Not applicable.

Conflicts of Interest: The authors declare no conflict of interest.

\section{References}

1. Hanahan, D.; Weinberg, R.A. Hallmarks of cancer: The next generation. Cell 2011, 144, 646-674. [CrossRef] [PubMed]

2. Martincorena, I.; Campbell, P.J. Somatic mutation in cancer and normal cells. Science 2015, 349, 1483-1489. [CrossRef] [PubMed]

3. Alexandrov, L.B.; Nik-Zainal, S.; Wedge, D.C.; Aparicio, S.A.; Behjati, S.; Biankin, A.V.; Bignell, G.R.; Bolli, N.; Borg, A.; Borresen-Dale, A.L.; et al. Signatures of mutational processes in human cancer. Nature 2013, 500, 415-421. [CrossRef] [PubMed]

4. Lawrence, M.S.; Stojanov, P.; Polak, P.; Kryukov, G.V.; Cibulskis, K.; Sivachenko, A.; Carter, S.L.; Stewart, C.; Mermel, C.H.; Roberts, S.A.; et al. Mutational heterogeneity in cancer and the search for new cancer-associated genes. Nature 2013, 499, 214-218. [CrossRef] [PubMed]

5. Tubbs, A.; Nussenzweig, A. Endogenous DNA Damage as a Source of Genomic Instability in Cancer. Cell 2017, 168, 644-656. [CrossRef]

6. Pilie, P.G.; Tang, C.; Mills, G.B.; Yap, T.A. State-of-the-art strategies for targeting the DNA damage response in cancer. Nat. Rev. Clin. Oncol. 2019, 16, 81-104. [CrossRef]

7. Caldecott, K.W. Mammalian DNA base excision repair: Dancing in the moonlight. DNA Repair 2020, 93, 102921. [CrossRef]

8. Beard, W.A.; Horton, J.K.; Prasad, R.; Wilson, S.H. Eukaryotic Base Excision Repair: New Approaches Shine Light on Mechanism. Annu. Rev. Biochem. 2019, 88, 137-162. [CrossRef]

9. Grundy, G.J.; Parsons, J.L. Base excision repair and its implications to cancer therapy. Essays Biochem. 2020, 64, 831-843. [CrossRef]

10. $\mathrm{Mu}, \mathrm{H}$.; Geacintov, N.E.; Broyde, S.; Yeo, J.E.; Scharer, O.D. Molecular basis for damage recognition and verification by XPCRAD23B and TFIIH in nucleotide excision repair. DNA Repair 2018, 71, 33-42. [CrossRef]

11. Kusakabe, M.; Onishi, Y.; Tada, H.; Kurihara, F.; Kusao, K.; Furukawa, M.; Iwai, S.; Yokoi, M.; Sakai, W.; Sugasawa, K. Mechanism and regulation of DNA damage recognition in nucleotide excision repair. Genes Env. 2019, 41, 2. [CrossRef] [PubMed]

12. Kumar, N.; Raja, S.; Van Houten, B. The involvement of nucleotide excision repair proteins in the removal of oxidative DNA damage. Nucleic Acids Res. 2020, 48, 11227-11243. [CrossRef]

13. Sugasawa, K. Mechanism and regulation of DNA damage recognition in mammalian nucleotide excision repair. Enzymes 2019, 45, 99-138. [CrossRef] [PubMed]

14. Apostolou, Z.; Chatzinikolaou, G.; Stratigi, K.; Garinis, G.A. Nucleotide Excision Repair and Transcription-Associated Genome Instability. Bioessays 2019, 41, e1800201. [CrossRef] [PubMed]

15. Zhao, B.; Rothenberg, E.; Ramsden, D.A.; Lieber, M.R. The molecular basis and disease relevance of non-homologous DNA end joining. Nat. Rev. Mol. Cell Biol. 2020, 21, 765-781. [CrossRef]

16. Chang, H.H.Y.; Pannunzio, N.R.; Adachi, N.; Lieber, M.R. Non-homologous DNA end joining and alternative pathways to double-strand break repair. Nat. Rev. Mol. Cell Biol. 2017, 18, 495-506. [CrossRef]

17. Pannunzio, N.R.; Watanabe, G.; Lieber, M.R. Nonhomologous DNA end-joining for repair of DNA double-strand breaks. J. Biol. Chem. 2018, 293, 10512-10523. [CrossRef]

18. Difilippantonio, M.J.; Zhu, J.; Chen, H.T.; Meffre, E.; Nussenzweig, M.C.; Max, E.E.; Ried, T.; Nussenzweig, A. DNA repair protein Ku80 suppresses chromosomal aberrations and malignant transformation. Nature 2000, 404, 510-514. [CrossRef]

19. Li, G.C.; Ouyang, H.; Li, X.; Nagasawa, H.; Little, J.B.; Chen, D.J.; Ling, C.C.; Fuks, Z.; Cordon-Cardo, C. Ku70: A candidate tumor suppressor gene for murine T cell lymphoma. Mol. Cell 1998, 2, 1-8. [CrossRef] 
20. Espejel, S.; Martin, M.; Klatt, P.; Martin-Caballero, J.; Flores, J.M.; Blasco, M.A. Shorter telomeres, accelerated ageing and increased lymphoma in DNA-PKcs-deficient mice. EMBO Rep. 2004, 5, 503-509. [CrossRef]

21. Myung, K.; Ghosh, G.; Fattah, F.J.; Li, G.; Kim, H.; Dutia, A.; Pak, E.; Smith, S.; Hendrickson, E.A. Regulation of telomere length and suppression of genomic instability in human somatic cells by Ku86. Mol. Cell Biol. 2004, 24, 5050-5059. [CrossRef] [PubMed]

22. Wang, Y.; Ghosh, G.; Hendrickson, E.A. Ku86 represses lethal telomere deletion events in human somatic cells. Proc. Natl. Acad. Sci. USA 2009, 106, 12430-12435. [CrossRef] [PubMed]

23. Zhao, W.; Wiese, C.; Kwon, Y.; Hromas, R.; Sung, P. The BRCA Tumor Suppressor Network in Chromosome Damage Repair by Homologous Recombination. Annu. Rev. Biochem. 2019, 88, 221-245. [CrossRef] [PubMed]

24. Blackford, A.N.; Jackson, S.P. ATM, ATR, and DNA-PK: The Trinity at the Heart of the DNA Damage Response. Mol. Cell 2017, 66, 801-817. [CrossRef] [PubMed]

25. Wright, W.D.; Shah, S.S.; Heyer, W.D. Homologous recombination and the repair of DNA double-strand breaks. J. Biol. Chem. 2018, 293, 10524-10535. [CrossRef]

26. Semmler, L.; Reiter-Brennan, C.; Klein, A. BRCA1 and Breast Cancer: A Review of the Underlying Mechanisms Resulting in the Tissue-Specific Tumorigenesis in Mutation Carriers. J. Breast Cancer 2019, 22, 1-14. [CrossRef]

27. Singh, A.K.; Yu, X. Tissue-Specific Carcinogens as Soil to Seed BRCA1/2-Mutant Hereditary Cancers. Trends Cancer 2020, 6, 559-568. [CrossRef]

28. Kantidze, O.L.; Velichko, A.K.; Luzhin, A.V.; Petrova, N.V.; Razin, S.V. Synthetically Lethal Interactions of ATM, ATR, and DNA-PKcs. Trends Cancer 2018, 4, 755-768. [CrossRef]

29. Menolfi, D.; Zha, S. ATM, ATR and DNA-PKcs kinases-the lessons from the mouse models: Inhibition not equal deletion. Cell Biosci. 2020, 10, 8. [CrossRef]

30. Bradbury, A.; Hall, S.; Curtin, N.; Drew, Y. Targeting ATR as Cancer Therapy: A new era for synthetic lethality and synergistic combinations? Pharm. Ther. 2020, 207, 107450. [CrossRef]

31. Ma, H.T.; Poon, R.Y.C. Aurora kinases and DNA damage response. Mutat. Res. Mol. Mech. Mutagen. 2020, 821, 111716. [CrossRef] [PubMed]

32. Krystyniak, A.; Garcia-Echeverria, C.; Prigent, C.; Ferrari, S. Inhibition of Aurora A in response to DNA damage. Oncogene 2006 25, 338-348. [CrossRef] [PubMed]

33. Macurek, L.; Lindqvist, A.; Lim, D.; Lampson, M.A.; Klompmaker, R.; Freire, R.; Clouin, C.; Taylor, S.S.; Yaffe, M.B.; Medema, R.H. Polo-like kinase-1 is activated by aurora A to promote checkpoint recovery. Nature 2008, 455, 119-123. [CrossRef] [PubMed]

34. Seki, A.; Coppinger, J.A.; Jang, C.Y.; Yates, J.R.; Fang, G. Bora and the kinase Aurora a cooperatively activate the kinase Plk1 and control mitotic entry. Science 2008, 320, 1655-1658. [CrossRef] [PubMed]

35. Allen, C.; Kurimasa, A.; Brenneman, M.A.; Chen, D.J.; Nickoloff, J.A. DNA-dependent protein kinase suppresses double-strand break-induced and spontaneous homologous recombination. Proc. Natl. Acad. Sci. USA 2002, 99, 3758-3763. [CrossRef]

36. Stiff, T.; O'Driscoll, M.; Rief, N.; Iwabuchi, K.; Lobrich, M.; Jeggo, P.A. ATM and DNA-PK function redundantly to phosphorylate H2AX after exposure to ionizing radiation. Cancer Res. 2004, 64, 2390-2396. [CrossRef]

37. Lord, C.J.; Ashworth, A. PARP inhibitors: Synthetic lethality in the clinic. Science 2017, 355, 1152-1158. [CrossRef]

38. Bryant, H.E.; Schultz, N.; Thomas, H.D.; Parker, K.M.; Flower, D.; Lopez, E.; Kyle, S.; Meuth, M.; Curtin, N.J.; Helleday, T. Specific killing of BRCA2-deficient tumours with inhibitors of poly(ADP-ribose) polymerase. Nature 2005, 434, 913-917. [CrossRef]

39. Farmer, H.; McCabe, N.; Lord, C.J.; Tutt, A.N.; Johnson, D.A.; Richardson, T.B.; Santarosa, M.; Dillon, K.J.; Hickson, I.; Knights, C.; et al. Targeting the DNA repair defect in BRCA mutant cells as a therapeutic strategy. Nature 2005, 434, 917-921. [CrossRef]

40. Fong, P.C.; Boss, D.S.; Yap, T.A.; Tutt, A.; Wu, P.; Mergui-Roelvink, M.; Mortimer, P.; Swaisland, H.; Lau, A.; O'Connor, M.J.; et al. Inhibition of poly(ADP-ribose) polymerase in tumors from BRCA mutation carriers. N. Engl. J. Med. 2009, 361, 123-134. [CrossRef]

41. Murai, J.; Huang, S.Y.; Das, B.B.; Renaud, A.; Zhang, Y.; Doroshow, J.H.; Ji, J.; Takeda, S.; Pommier, Y. Trapping of PARP1 and PARP2 by Clinical PARP Inhibitors. Cancer Res. 2012, 72, 5588-5599. [CrossRef] [PubMed]

42. Murai, J.; Huang, S.Y.; Renaud, A.; Zhang, Y.; Ji, J.; Takeda, S.; Morris, J.; Teicher, B.; Doroshow, J.H.; Pommier, Y. Stereospecific PARP trapping by BMN 673 and comparison with olaparib and rucaparib. Mol. Cancer Ther. 2014, 13, 433-443. [CrossRef] [PubMed]

43. Pommier, Y.; O'Connor, M.J.; de Bono, J. Laying a trap to kill cancer cells: PARP inhibitors and their mechanisms of action. Sci. Transl. Med. 2016, 8, 362ps317. [CrossRef] [PubMed]

44. Cong, K.; Peng, M.; Kousholt, A.N.; Lee, W.T.C.; Lee, S.; Nayak, S.; Krais, J.; VanderVere-Carozza, P.S.; Pawelczak, K.S.; Calvo, J.; et al. Replication gaps are a key determinant of PARP inhibitor synthetic lethality with BRCA deficiency. Mol. Cell 2021, 81, 3128-3144. [CrossRef]

45. Panzarino, N.J.; Krais, J.J.; Cong, K.; Peng, M.; Mosqueda, M.; Nayak, S.U.; Bond, S.M.; Calvo, J.A.; Doshi, M.B.; Bere, M.; et al. Replication Gaps Underlie BRCA Deficiency and Therapy Response. Cancer Res. 2021, 81, 1388-1397. [CrossRef]

46. Cliby, W.A.; Roberts, C.J.; Cimprich, K.A.; Stringer, C.M.; Lamb, J.R.; Schreiber, S.L.; Friend, S.H. Overexpression of a kinaseinactive ATR protein causes sensitivity to DNA-damaging agents and defects in cell cycle checkpoints. EMBO J. 1998, 17, 159-169. [CrossRef]

47. Rundle, S.; Bradbury, A.; Drew, Y.; Curtin, N.J. Targeting the ATR-CHK1 Axis in Cancer Therapy. Cancers 2017, 9, 41. [CrossRef] 
48. Charrier, J.D.; Durrant, S.J.; Golec, J.M.; Kay, D.P.; Knegtel, R.M.; MacCormick, S.; Mortimore, M.; O’Donnell, M.E.; Pinder, J.L.; Reaper, P.M.; et al. Discovery of potent and selective inhibitors of ataxia telangiectasia mutated and Rad3 related (ATR) protein kinase as potential anticancer agents. J. Med. Chem. 2011, 54, 2320-2330. [CrossRef]

49. Fokas, E.; Prevo, R.; Pollard, J.R.; Reaper, P.M.; Charlton, P.A.; Cornelissen, B.; Vallis, K.A.; Hammond, E.M.; Olcina, M.M.; Gillies McKenna, W.; et al. Targeting ATR in vivo using the novel inhibitor VE-822 results in selective sensitization of pancreatic tumors to radiation. Cell Death Dis. 2012, 3, e441. [CrossRef]

50. Knegtel, R.; Charrier, J.D.; Durrant, S.; Davis, C.; O’Donnell, M.; Storck, P.; MacCormick, S.; Kay, D.; Pinder, J.; Virani, A.; et al. Rational Design of 5-(4-(Isopropylsulfonyl)phenyl)-3-(3-(4-((methylamino)methyl)phenyl)isoxazol-5-yl)pyrazin-2-amine (VX-970, M6620): Optimization of Intra- and Intermolecular Polar Interactions of a New Ataxia Telangiectasia Mutated and Rad3-Related (ATR) Kinase Inhibitor. J. Med. Chem. 2019, 62, 5547-5561. [CrossRef]

51. Thomas, A.; Redon, C.E.; Sciuto, L.; Padiernos, E.; Ji, J.; Lee, M.J.; Yuno, A.; Lee, S.; Zhang, Y.; Tran, L.; et al. Phase I Study of ATR Inhibitor M6620 in Combination With Topotecan in Patients With Advanced Solid Tumors. J. Clin. Oncol. 2018, 36, $1594-1602$. [CrossRef] [PubMed]

52. Yap, T.A.; O'Carrigan, B.; Penney, M.S.; Lim, J.S.; Brown, J.S.; de Miguel Luken, M.J.; Tunariu, N.; Perez-Lopez, R.; Rodrigues, D.N.; Riisnaes, R.; et al. Phase I Trial of First-in-Class ATR Inhibitor M6620 (VX-970) as Monotherapy or in Combination With Carboplatin in Patients With Advanced Solid Tumors. J. Clin. Oncol. 2020, 38, 3195-3204. [CrossRef]

53. Shapiro, G.I.; Wesolowski, R.; Devoe, C.; Lord, S.; Pollard, J.; Hendriks, B.S.; Falk, M.; Diaz-Padilla, I.; Plummer, R.; Yap, T.A. Phase 1 study of the ATR inhibitor berzosertib in combination with cisplatin in patients with advanced solid tumours. Br. J. Cancer 2021, 125, 520-527. [CrossRef] [PubMed]

54. Middleton, M.R.; Dean, E.; Evans, T.R.J.; Shapiro, G.I.; Pollard, J.; Hendriks, B.S.; Falk, M.; Diaz-Padilla, I.; Plummer, R. Phase 1 study of the ATR inhibitor berzosertib (formerly M6620, VX-970) combined with gemcitabine +/- cisplatin in patients with advanced solid tumours. Br. J. Cancer 2021, 125, 510-519. [CrossRef]

55. Konstantinopoulos, P.A.; Cheng, S.C.; Wahner Hendrickson, A.E.; Penson, R.T.; Schumer, S.T.; Doyle, L.A.; Lee, E.K.; Kohn, E.C.; Duska, L.R.; Crispens, M.A.; et al. Berzosertib plus gemcitabine versus gemcitabine alone in platinum-resistant high-grade serous ovarian cancer: A multicentre, open-label, randomised, phase 2 trial. Lancet Oncol. 2020, 21, 957-968. [CrossRef]

56. Pal, S.K.; Frankel, P.H.; Mortazavi, A.; Milowsky, M.; Vaishampayan, U.; Parikh, M.; Lyou, Y.; Weng, P.; Parikh, R.; Teply, B.; et al. Effect of Cisplatin and Gemcitabine With or Without Berzosertib in Patients With Advanced Urothelial Carcinoma: A Phase 2 Randomized Clinical Trial. JAMA Oncol. 2021, 7, 1536. [CrossRef] [PubMed]

57. Foote, K.M.; Blades, K.; Cronin, A.; Fillery, S.; Guichard, S.S.; Hassall, L.; Hickson, I.; Jacq, X.; Jewsbury, P.J.; McGuire, T.M.; et al. Discovery of 4-\{4-[(3R)-3-Methylmorpholin-4-yl]-6-[1-(methylsulfonyl)cyclopropyl]pyrimidin-2-y 1\}-1H-indole (AZ20): A potent and selective inhibitor of ATR protein kinase with monotherapy in vivo antitumor activity. J. Med. Chem. 2013, 56, 2125-2138. [CrossRef]

58. Foote, K.M.; Nissink, J.W.M.; McGuire, T.; Turner, P.; Guichard, S.; Yates, J.W.T.; Lau, A.; Blades, K.; Heathcote, D.; Odedra, R.; et al. Discovery and Characterization of AZD6738, a Potent Inhibitor of Ataxia Telangiectasia Mutated and Rad3 Related (ATR) Kinase with Application as an Anticancer Agent. J. Med. Chem. 2018, 61, 9889-9907. [CrossRef]

59. Kim, S.T.; Smith, S.A.; Mortimer, P.; Loembe, A.B.; Cho, H.; Kim, K.M.; Smith, C.; Willis, S.; Irurzun-Arana, I.; Berges, A.; et al. Phase I Study of Ceralasertib (AZD6738), a Novel DNA Damage Repair Agent, in Combination with Weekly Paclitaxel in Refractory Cancer. Clin. Cancer Res. 2021, 27, 4700-4709. [CrossRef]

60. Yap, T.A.; Krebs, M.G.; Postel-Vinay, S.; El-Khouiery, A.; Soria, J.C.; Lopez, J.; Berges, A.; Cheung, S.A.; Irurzun-Arana, I.; Goldwin, A.; et al. Ceralasertib (AZD6738), an Oral ATR Kinase Inhibitor, in Combination with Carboplatin in Patients with Advanced Solid Tumors: A Phase I Study. Clin. Cancer Res. 2021, 27, 5213-5224. [CrossRef]

61. Lucking, U.; Wortmann, L.; Wengner, A.M.; Lefranc, J.; Lienau, P.; Briem, H.; Siemeister, G.; Bomer, U.; Denner, K.; Schafer, M.; et al. Damage Incorporated: Discovery of the Potent, Highly Selective, Orally Available ATR Inhibitor BAY 1895344 with Favorable Pharmacokinetic Properties and Promising Efficacy in Monotherapy and in Combination Treatments in Preclinical Tumor Models. J. Med. Chem. 2020, 63, 7293-7325. [CrossRef] [PubMed]

62. Wengner, A.M.; Siemeister, G.; Lucking, U.; Lefranc, J.; Wortmann, L.; Lienau, P.; Bader, B.; Bomer, U.; Moosmayer, D.; Eberspacher, U.; et al. The Novel ATR Inhibitor BAY 1895344 Is Efficacious as Monotherapy and Combined with DNA DamageInducing or Repair-Compromising Therapies in Preclinical Cancer Models. Mol. Cancer Ther. 2020, 19, 26-38. [CrossRef] [PubMed]

63. Yap, T.A.; Tan, D.S.P.; Terbuch, A.; Caldwell, R.; Guo, C.; Goh, B.C.; Heong, V.; Haris, N.R.M.; Bashir, S.; Drew, Y.; et al. First-inHuman Trial of the Oral Ataxia Telangiectasia and RAD3-Related (ATR) Inhibitor BAY 1895344 in Patients with Advanced Solid Tumors. Cancer Discov. 2021, 11, 80-91. [CrossRef] [PubMed]

64. Jo, U.; Senatorov, I.S.; Zimmermann, A.; Saha, L.K.; Murai, Y.; Kim, S.H.; Rajapakse, V.N.; Elloumi, F.; Takahashi, N.; Schultz, C.W.; et al. Novel and Highly Potent ATR Inhibitor M4344 Kills Cancer Cells With Replication Stress, and Enhances the Chemotherapeutic Activity of Widely Used DNA Damaging Agents. Mol. Cancer Ther. 2021, 20, 1431-1441. [CrossRef]

65. Kim, R.; Kwon, M.; An, M.; Kim, S.T.; Smith, S.A.; Loembe, A.B.; Mortimer, P.G.S.; Armenia, J.; Lukashchuk, N.; Shah, N.; et al Phase II study of ceralasertib (AZD6738) in combination with durvalumab in patients with advanced/metastatic melanoma who have failed prior anti-PD-1 therapy. Ann. Oncol. 2021, 33, 192-203. [CrossRef]

66. Sarkaria, J.N.; Eshleman, J.S. ATM as a target for novel radiosensitizers. Semin. Radiat. Oncol. 2001, 11, 316-327. [CrossRef] 
67. Hickson, I.; Zhao, Y.; Richardson, C.J.; Green, S.J.; Martin, N.M.; Orr, A.I.; Reaper, P.M.; Jackson, S.P.; Curtin, N.J.; Smith, G.C. Identification and characterization of a novel and specific inhibitor of the ataxia-telangiectasia mutated kinase ATM. Cancer Res. 2004, 64, 9152-9159. [CrossRef]

68. Golding, S.E.; Rosenberg, E.; Valerie, N.; Hussaini, I.; Frigerio, M.; Cockcroft, X.F.; Chong, W.Y.; Hummersone, M.; Rigoreau, L.; Menear, K.A.; et al. Improved ATM kinase inhibitor KU-60019 radiosensitizes glioma cells, compromises insulin, AKT and ERK prosurvival signaling, and inhibits migration and invasion. Mol. Cancer Ther. 2009, 8, 2894-2902. [CrossRef]

69. Pike, K.G.; Barlaam, B.; Cadogan, E.; Campbell, A.; Chen, Y.; Colclough, N.; Davies, N.L.; de-Almeida, C.; Degorce, S.L.; Didelot, M.; et al. The Identification of Potent, Selective, and Orally Available Inhibitors of Ataxia Telangiectasia Mutated (ATM) Kinase: The Discovery of AZD0156 (8-\{6-[3-(Dimethylamino)propoxy]pyridin-3-yl\}-3-methyl-1-(tetrahydro-2 H-pyran-4-yl)-1,3dihydro-2 H-imidazo[4,5-c]quinolin-2-one). J. Med. Chem. 2018, 61, 3823-3841. [CrossRef]

70. Durant, S.T.; Zheng, L.; Wang, Y.; Chen, K.; Zhang, L.; Zhang, T.; Yang, Z.; Riches, L.; Trinidad, A.G.; Fok, J.H.L.; et al. The brain-penetrant clinical ATM inhibitor AZD1390 radiosensitizes and improves survival of preclinical brain tumor models. Sci. Adv. 2018, 4, eaat1719. [CrossRef]

71. Fuchss, T.; Mederski, W.W.; Zenke, F.T.; Dahmen, H.; Zimmermann, A.; Blaukat, A. Abstract 329: Highly potent and selective ATM kinase inhibitor M3541: A clinical candidate drug with strong antitumor activity in combination with radiotherapy. Cancer Res. 2018, 78, 329. [CrossRef]

72. Zimmermann, A.; Zenke, F.; Dahmen, H.; Sirrenberg, C.; Grombacher, T.; Vassilev, L.T.; Fuchss, T.; Blaukat, A. Abstract 338: A new investigational ATM Inhibitor, M3541, synergistically potentiates fractionated radiotherapy and chemotherapy in cancer cells and animal models. Cancer Res. 2018, 78, 338. [CrossRef]

73. Medova, M.; Medo, M.; Hovhannisyan, L.; Munoz-Maldonado, C.; Aebersold, D.M.; Zimmer, Y. DNA-PK in human malignant disorders: Mechanisms and implications for pharmacological interventions. Pharm. Ther. 2020, 215, 107617. [CrossRef] [PubMed]

74. Mortensen, D.S.; Perrin-Ninkovic, S.M.; Shevlin, G.; Elsner, J.; Zhao, J.; Whitefield, B.; Tehrani, L.; Sapienza, J.; Riggs, J.R.; Parnes, J.S.; et al. Optimization of a Series of Triazole Containing Mammalian Target of Rapamycin (mTOR) Kinase Inhibitors and the Discovery of CC-115. J. Med. Chem. 2015, 58, 5599-5608. [CrossRef] [PubMed]

75. Tsuji, T.; Sapinoso, L.M.; Tran, T.; Gaffney, B.; Wong, L.; Sankar, S.; Raymon, H.K.; Mortensen, D.S.; Xu, S. CC-115, a dual inhibitor of mTOR kinase and DNA-PK, blocks DNA damage repair pathways and selectively inhibits ATM-deficient cell growth in vitro. Oncotarget 2017, 8, 74688-74702. [CrossRef] [PubMed]

76. Thijssen, R.; Ter Burg, J.; Garrick, B.; van Bochove, G.G.; Brown, J.R.; Fernandes, S.M.; Rodriguez, M.S.; Michot, J.M.; Hallek, M.; Eichhorst, B.; et al. Dual TORK/DNA-PK inhibition blocks critical signaling pathways in chronic lymphocytic leukemia. Blood 2016, 128, 574-583. [CrossRef]

77. Munster, P.; Mita, M.; Mahipal, A.; Nemunaitis, J.; Massard, C.; Mikkelsen, T.; Cruz, C.; Paz-Ares, L.; Hidalgo, M.; Rathkopf, D.; et al. First-In-Human Phase I Study Of A Dual mTOR Kinase And DNA-PK Inhibitor (CC-115) In Advanced Malignancy. Cancer Manag. Res. 2019, 11, 10463-10476. [CrossRef]

78. Klein, C.; Dokic, I.; Mairani, A.; Mein, S.; Brons, S.; Haring, P.; Haberer, T.; Jakel, O.; Zimmermann, A.; Zenke, F.; et al. Overcoming hypoxia-induced tumor radioresistance in non-small cell lung cancer by targeting DNA-dependent protein kinase in combination with carbon ion irradiation. Radiat. Oncol. 2017, 12, 208. [CrossRef]

79. Wise, H.C.; Iyer, G.V.; Moore, K.; Temkin, S.M.; Gordon, S.; Aghajanian, C.; Grisham, R.N. Activity of M3814, an Oral DNA-PK Inhibitor, In Combination with Topoisomerase II Inhibitors in Ovarian Cancer Models. Sci. Rep. 2019, 9, 18882. [CrossRef]

80. Zenke, F.T.; Zimmermann, A.; Sirrenberg, C.; Dahmen, H.; Kirkin, V.; Pehl, U.; Grombacher, T.; Wilm, C.; Fuchss, T.; Amendt, C.; et al. Pharmacologic Inhibitor of DNA-PK, M3814, Potentiates Radiotherapy and Regresses Human Tumors in Mouse Models. Mol. Cancer Ther. 2020, 19, 1091-1101. [CrossRef]

81. van Bussel, M.T.J.; Awada, A.; de Jonge, M.J.A.; Mau-Sorensen, M.; Nielsen, D.; Schoffski, P.; Verheul, H.M.W.; Sarholz, B.; Berghoff, K.; El Bawab, S.; et al. A first-in-man phase 1 study of the DNA-dependent protein kinase inhibitor peposertib (formerly M3814) in patients with advanced solid tumours. Br. J. Cancer 2021, 124, 728-735. [CrossRef] [PubMed]

82. Fok, J.H.L.; Ramos-Montoya, A.; Vazquez-Chantada, M.; Wijnhoven, P.W.G.; Follia, V.; James, N.; Farrington, P.M.; Karmokar, A.; Willis, S.E.; Cairns, J.; et al. AZD7648 is a potent and selective DNA-PK inhibitor that enhances radiation, chemotherapy and olaparib activity. Nat. Commun. 2019, 10, 5065. [CrossRef] [PubMed]

83. Goldberg, F.W.; Finlay, M.R.V.; Ting, A.K.T.; Beattie, D.; Lamont, G.M.; Fallan, C.; Wrigley, G.L.; Schimpl, M.; Howard, M.R.; Williamson, B.; et al. The Discovery of 7-Methyl-2-[(7-methyl[1,2,4]triazolo[1,5-a]pyridin-6-yl)amino]-9-(tetrahydro-2H-p yran-4yl)-7,9-dihydro-8H-purin-8-one (AZD7648), a Potent and Selective DNA-Dependent Protein Kinase (DNA-PK) Inhibitor. J. Med. Chem. 2020, 63, 3461-3471. [CrossRef] [PubMed]

84. Welch, S.; Hirte, H.W.; Carey, M.S.; Hotte, S.J.; Tsao, M.S.; Brown, S.; Pond, G.R.; Dancey, J.E.; Oza, A.M. UCN-01 in combination with topotecan in patients with advanced recurrent ovarian cancer: A study of the Princess Margaret Hospital Phase II consortium. Gynecol. Oncol. 2007, 106, 305-310. [CrossRef]

85. Ma, C.X.; Ellis, M.J.; Petroni, G.R.; Guo, Z.; Cai, S.R.; Ryan, C.E.; Craig Lockhart, A.; Naughton, M.J.; Pluard, T.J.; Brenin, C.M.; et al. A phase II study of UCN-01 in combination with irinotecan in patients with metastatic triple negative breast cancer. Breast Cancer Res. Treat. 2013, 137, 483-492. [CrossRef] 
86. Seto, T.; Esaki, T.; Hirai, F.; Arita, S.; Nosaki, K.; Makiyama, A.; Kometani, T.; Fujimoto, C.; Hamatake, M.; Takeoka, H.; et al. Phase I, dose-escalation study of AZD7762 alone and in combination with gemcitabine in Japanese patients with advanced solid tumours. Cancer Chemother. Pharmacol. 2013, 72, 619-627. [CrossRef]

87. Sausville, E.; Lorusso, P.; Carducci, M.; Carter, J.; Quinn, M.F.; Malburg, L.; Azad, N.; Cosgrove, D.; Knight, R.; Barker, P.; et al. Phase I dose-escalation study of AZD7762, a checkpoint kinase inhibitor, in combination with gemcitabine in US patients with advanced solid tumors. Cancer Chemother. Pharmacol. 2014, 73, 539-549. [CrossRef]

88. Laquente, B.; Lopez-Martin, J.; Richards, D.; Illerhaus, G.; Chang, D.Z.; Kim, G.; Stella, P.; Richel, D.; Szcylik, C.; Cascinu, S.; et al. A phase II study to evaluate LY2603618 in combination with gemcitabine in pancreatic cancer patients. BMC Cancer 2017, 17, 137. [CrossRef]

89. Wehler, T.; Thomas, M.; Schumann, C.; Bosch-Barrera, J.; Vinolas Segarra, N.; Dickgreber, N.J.; Dalhoff, K.; Sebastian, M.; Corral Jaime, J.; Alonso, M.; et al. A randomized, phase 2 evaluation of the CHK1 inhibitor, LY2603618, administered in combination with pemetrexed and cisplatin in patients with advanced nonsquamous non-small cell lung cancer. Lung Cancer 2017, 108, 212-216. [CrossRef]

90. Daud, A.I.; Ashworth, M.T.; Strosberg, J.; Goldman, J.W.; Mendelson, D.; Springett, G.; Venook, A.P.; Loechner, S.; Rosen, L.S.; Shanahan, F.; et al. Phase I dose-escalation trial of checkpoint kinase 1 inhibitor MK-8776 as monotherapy and in combination with gemcitabine in patients with advanced solid tumors. J. Clin. Oncol. 2015, 33, 1060-1066. [CrossRef]

91. Italiano, A.; Infante, J.R.; Shapiro, G.I.; Moore, K.N.; LoRusso, P.M.; Hamilton, E.; Cousin, S.; Toulmonde, M.; Postel-Vinay, S.; Tolaney, S.; et al. Phase I study of the checkpoint kinase 1 inhibitor GDC-0575 in combination with gemcitabine in patients with refractory solid tumors. Ann. Oncol. 2018, 29, 1304-1311. [CrossRef] [PubMed]

92. King, C.; Diaz, H.B.; McNeely, S.; Barnard, D.; Dempsey, J.; Blosser, W.; Beckmann, R.; Barda, D.; Marshall, M.S. LY2606368 Causes Replication Catastrophe and Antitumor Effects through CHK1-Dependent Mechanisms. Mol. Cancer 2015, 14, 2004-2013. [CrossRef] [PubMed]

93. Hong, D.; Infante, J.; Janku, F.; Jones, S.; Nguyen, L.M.; Burris, H.; Naing, A.; Bauer, T.M.; Piha-Paul, S.; Johnson, F.M.; et al. Phase I Study of LY2606368, a Checkpoint Kinase 1 Inhibitor, in Patients With Advanced Cancer. J. Clin. Oncol. 2016, 34, $1764-1771$. [CrossRef] [PubMed]

94. Iwasa, S.; Yamamoto, N.; Shitara, K.; Tamura, K.; Matsubara, N.; Tajimi, M.; Lin, A.B.; Asou, H.; Cai, Z.; Inoue, K.; et al. Dose-finding study of the checkpoint kinase 1 inhibitor, prexasertib, in Japanese patients with advanced solid tumors. Cancer Sci. 2018, 109, 3216-3223. [CrossRef]

95. Lee, J.M.; Nair, J.; Zimmer, A.; Lipkowitz, S.; Annunziata, C.M.; Merino, M.J.; Swisher, E.M.; Harrell, M.I.; Trepel, J.B.; Lee, M.J.; et al. Prexasertib, a cell cycle checkpoint kinase 1 and 2 inhibitor, in BRCA wild-type recurrent high-grade serous ovarian cancer: A first-in-class proof-of-concept phase 2 study. Lancet Oncol. 2018, 19, 207-215. [CrossRef]

96. Gatti-Mays, M.E.; Karzai, F.H.; Soltani, S.N.; Zimmer, A.; Green, J.E.; Lee, M.J.; Trepel, J.B.; Yuno, A.; Lipkowitz, S.; Nair, J.; et al. A Phase II Single Arm Pilot Study of the CHK1 Inhibitor Prexasertib (LY2606368) in BRCA Wild-Type, Advanced Triple-Negative Breast Cancer. Oncologist 2020, 25, 1013-e1824. [CrossRef]

97. Byers, L.A.; Navarro, A.; Schaefer, E.; Johnson, M.; Ozguroglu, M.; Han, J.Y.; Bondarenko, I.; Cicin, I.; Dragnev, K.H.; Abel, A.; et al. A Phase II Trial of Prexasertib (LY2606368) in Patients With Extensive-Stage Small-Cell Lung Cancer. Clin. Lung Cancer 2021, 22, 531-540. [CrossRef]

98. Moore, K.N.; Hong, D.S.; Patel, M.R.; Pant, S.; Ulahannan, S.V.; Jones, S.; Meric-Bernstam, F.; Wang, J.S.; Aljumaily, R.; Hamilton, E.P.; et al. A Phase $1 \mathrm{~b}$ Trial of Prexasertib in Combination with Standard-of-Care Agents in Advanced or Metastatic Cancer. Target Oncol. 2021, 16, 569-589. [CrossRef]

99. Do, K.T.; Kochupurakkal, B.; Kelland, S.; de Jonge, A.; Hedglin, J.; Powers, A.; Quinn, N.; Gannon, C.; Vuong, L.; Parmar, K.; et al. Phase 1 Combination Study of the CHK1 Inhibitor Prexasertib and the PARP Inhibitor Olaparib in High-grade Serous Ovarian Cancer and Other Solid Tumors. Clin. Cancer Res. 2021, 27, 4710-4716. [CrossRef]

100. Do, K.T.; Manuszak, C.; Thrash, E.; Giobbie-Hurder, A.; Hu, J.; Kelland, S.; Powers, A.; de Jonge, A.; Shapiro, G.I.; Severgnini, M. Immune modulating activity of the CHK1 inhibitor prexasertib and anti-PD-L1 antibody LY3300054 in patients with high-grade serous ovarian cancer and other solid tumors. Cancer Immunol. Immunother. 2021, 70, 2991-3000. [CrossRef]

101. Esposito, F.; Giuffrida, R.; Raciti, G.; Puglisi, C.; Forte, S. Wee1 Kinase: A Potential Target to Overcome Tumor Resistance to Therapy. Int. J. Mol. Sci. 2021, 22, 10689. [CrossRef] [PubMed]

102. Aarts, M.; Sharpe, R.; Garcia-Murillas, I.; Gevensleben, H.; Hurd, M.S.; Shumway, S.D.; Toniatti, C.; Ashworth, A.; Turner, N.C. Forced mitotic entry of S-phase cells as a therapeutic strategy induced by inhibition of WEE1. Cancer Discov. 2012, 2, 524-539. [CrossRef] [PubMed]

103. Hirai, H.; Iwasawa, Y.; Okada, M.; Arai, T.; Nishibata, T.; Kobayashi, M.; Kimura, T.; Kaneko, N.; Ohtani, J.; Yamanaka, K.; et al. Small-molecule inhibition of Wee1 kinase by MK-1775 selectively sensitizes p53-deficient tumor cells to DNA-damaging agents. Mol. Cancer Ther. 2009, 8, 2992-3000. [CrossRef] [PubMed]

104. Do, K.; Wilsker, D.; Ji, J.; Zlott, J.; Freshwater, T.; Kinders, R.J.; Collins, J.; Chen, A.P.; Doroshow, J.H.; Kummar, S. Phase I Study of Single-Agent AZD1775 (MK-1775), a Wee1 Kinase Inhibitor, in Patients With Refractory Solid Tumors. J. Clin. Oncol. 2015, 33, 3409-3415. [CrossRef] 
105. Leijen, S.; van Geel, R.M.; Pavlick, A.C.; Tibes, R.; Rosen, L.; Razak, A.R.; Lam, R.; Demuth, T.; Rose, S.; Lee, M.A.; et al. Phase I Study Evaluating WEE1 Inhibitor AZD1775 As Monotherapy and in Combination With Gemcitabine, Cisplatin, or Carboplatin in Patients With Advanced Solid Tumors. J. Clin. Oncol. 2016, 34, 4371-4380. [CrossRef]

106. Cuneo, K.C.; Morgan, M.A.; Sahai, V.; Schipper, M.J.; Parsels, L.A.; Parsels, J.D.; Devasia, T.; Al-Hawaray, M.; Cho, C.S.; Nathan, H.; et al. Dose Escalation Trial of the Wee1 Inhibitor Adavosertib (AZD1775) in Combination With Gemcitabine and Radiation for Patients With Locally Advanced Pancreatic Cancer. J. Clin. Oncol. 2019, 37, 2643-2650. [CrossRef]

107. Chera, B.S.; Sheth, S.H.; Patel, S.A.; Goldin, D.; Douglas, K.E.; Green, R.L.; Shen, C.J.; Gupta, G.P.; Moore, D.T.; Grilley Olson, J.E.; et al. Phase 1 trial of adavosertib (AZD1775) in combination with concurrent radiation and cisplatin for intermediate-risk and high-risk head and neck squamous cell carcinoma. Cancer 2021, 127, 4447-4454. [CrossRef]

108. Leijen, S.; van Geel, R.M.; Sonke, G.S.; de Jong, D.; Rosenberg, E.H.; Marchetti, S.; Pluim, D.; van Werkhoven, E.; Rose, S.; Lee, M.A.; et al. Phase II Study of WEE1 Inhibitor AZD1775 Plus Carboplatin in Patients With TP53-Mutated Ovarian Cancer Refractory or Resistant to First-Line Therapy Within 3 Months. J. Clin. Oncol. 2016, 34, 4354-4361. [CrossRef]

109. Oza, A.M.; Estevez-Diz, M.; Grischke, E.M.; Hall, M.; Marme, F.; Provencher, D.; Uyar, D.; Weberpals, J.I.; Wenham, R.M.; Laing, N.; et al. A Biomarker-enriched, Randomized Phase II Trial of Adavosertib (AZD1775) Plus Paclitaxel and Carboplatin for Women with Platinum-sensitive TP53-mutant Ovarian Cancer. Clin. Cancer Res. 2020, 26, 4767-4776. [CrossRef]

110. Lheureux, S.; Cristea, M.C.; Bruce, J.P.; Garg, S.; Cabanero, M.; Mantia-Smaldone, G.; Olawaiye, A.B.; Ellard, S.L.; Weberpals, J.I.; Wahner Hendrickson, A.E.; et al. Adavosertib plus gemcitabine for platinum-resistant or platinum-refractory recurrent ovarian cancer: A double-blind, randomised, placebo-controlled, phase 2 trial. Lancet 2021, 397, 281-292. [CrossRef]

111. Moore, K.N.; Chambers, S.K.; Hamilton, E.P.; Chen, L.M.; Oza, A.M.; Ghamande, S.A.; Konecny, G.E.; Plaxe, S.C.; Spitz, D.L.; Geenen, J.J.J.; et al. Adavosertib with Chemotherapy in Patients with Primary Platinum-Resistant Ovarian, Fallopian Tube, or Peritoneal Cancer: An Open-Label, Four-Arm, Phase II Study. Clin. Cancer Res. 2021, 28, 36-44. [CrossRef] [PubMed]

112. Keenan, T.E.; Li, T.; Vallius, T.; Guerriero, J.L.; Tayob, N.; Kochupurakkal, B.; Davis, J.; Pastorello, R.; Tahara, R.K.; Anderson, L.; et al. Clinical Efficacy and Molecular Response Correlates of the WEE1 Inhibitor Adavosertib Combined with Cisplatin in Patients with Metastatic Triple-Negative Breast Cancer. Clin. Cancer Res. 2021, 27, 983-991. [CrossRef] [PubMed]

113. Seligmann, J.F.; Fisher, D.J.; Brown, L.C.; Adams, R.A.; Graham, J.; Quirke, P.; Richman, S.D.; Butler, R.; Domingo, E.; Blake, A.; et al. Inhibition of WEE1 Is Effective in TP53- and RAS-Mutant Metastatic Colorectal Cancer: A Randomized Trial (FOCUS4-C) Comparing Adavosertib (AZD1775) With Active Monitoring. J. Clin. Oncol. 2021, 39, 3705-3715. [CrossRef] [PubMed]

114. Park, S.; Shim, J.; Mortimer, P.G.S.; Smith, S.A.; Godin, R.E.; Hollingsworth, S.J.; Kim, H.J.; Jung, H.A.; Sun, J.M.; Park, W.Y.; et al. Biomarker-driven phase 2 umbrella trial study for patients with recurrent small cell lung cancer failing platinum-based chemotherapy. Cancer 2020, 126, 4002-4012. [CrossRef]

115. Liu, J.F.; Xiong, N.; Campos, S.M.; Wright, A.A.; Krasner, C.; Schumer, S.; Horowitz, N.; Veneris, J.; Tayob, N.; Morrissey, S.; et al. Phase II Study of the WEE1 Inhibitor Adavosertib in Recurrent Uterine Serous Carcinoma. J. Clin. Oncol. 2021, 39, 1531-1539. [CrossRef]

116. Chen, A.P.; Kummar, S.; Moore, N.; Rubinstein, L.V.; Zhao, Y.; Williams, P.M.; Palmisano, A.; Sims, D.; O’Sullivan Coyne, G.; Rosenberger, C.L.; et al. Molecular Profiling-Based Assignment of Cancer Therapy (NCI-MPACT): A Randomized Multicenter Phase II Trial. JCO Precis. Oncol. 2021, 5, 133-144. [CrossRef] [PubMed]

117. Rudolph, D.; Steegmaier, M.; Hoffmann, M.; Grauert, M.; Baum, A.; Quant, J.; Haslinger, C.; Garin-Chesa, P.; Adolf, G.R. BI 6727, a Polo-like kinase inhibitor with improved pharmacokinetic profile and broad antitumor activity. Clin. Cancer Res. 2009, 15, 3094-3102. [CrossRef] [PubMed]

118. Schoffski, P.; Awada, A.; Dumez, H.; Gil, T.; Bartholomeus, S.; Wolter, P.; Taton, M.; Fritsch, H.; Glomb, P.; Munzert, G. A phase I, dose-escalation study of the novel Polo-like kinase inhibitor volasertib (BI 6727) in patients with advanced solid tumours. Eur. J. Cancer 2012, 48, 179-186. [CrossRef]

119. Stadler, W.M.; Vaughn, D.J.; Sonpavde, G.; Vogelzang, N.J.; Tagawa, S.T.; Petrylak, D.P.; Rosen, P.; Lin, C.C.; Mahoney, J.; Modi, S.; et al. An open-label, single-arm, phase 2 trial of the Polo-like kinase inhibitor volasertib (BI 6727) in patients with locally advanced or metastatic urothelial cancer. Cancer 2014, 120, 976-982. [CrossRef]

120. Dohner, H.; Lubbert, M.; Fiedler, W.; Fouillard, L.; Haaland, A.; Brandwein, J.M.; Lepretre, S.; Reman, O.; Turlure, P.; Ottmann, O.G.; et al. Randomized, phase 2 trial of low-dose cytarabine with or without volasertib in AML patients not suitable for induction therapy. Blood 2014, 124, 1426-1433. [CrossRef]

121. Dohner, H.; Symeonidis, A.; Deeren, D.; Demeter, J.; Sanz, M.A.; Anagnostopoulos, A.; Esteve, J.; Fiedler, W.; Porkka, K.; Kim, H.J.; et al. Adjunctive Volasertib in Patients With Acute Myeloid Leukemia not Eligible for Standard Induction Therapy: A Randomized, Phase 3 Trial. Hemasphere 2021, 5, e617. [CrossRef] [PubMed]

122. Ellis, P.M.; Leighl, N.B.; Hirsh, V.; Reaume, M.N.; Blais, N.; Wierzbicki, R.; Sadrolhefazi, B.; Gu, Y.; Liu, D.; Pilz, K.; et al. A Randomized, Open-Label Phase II Trial of Volasertib as Monotherapy and in Combination With Standard-Dose Pemetrexed Compared With Pemetrexed Monotherapy in Second-Line Treatment for Non-Small-Cell Lung Cancer. Clin. Lung Cancer 2015, 16, 457-465. [CrossRef] [PubMed]

123. Pujade-Lauraine, E.; Selle, F.; Weber, B.; Ray-Coquard, I.L.; Vergote, I.; Sufliarsky, J.; Del Campo, J.M.; Lortholary, A.; Lesoin, A.; Follana, P.; et al. Volasertib Versus Chemotherapy in Platinum-Resistant or -Refractory Ovarian Cancer: A Randomized Phase II 
Groupe des Investigateurs Nationaux pour l'Etude des Cancers de l'Ovaire Study. J. Clin. Oncol. 2016, 34, 706-713. [CrossRef] [PubMed]

124. Valsasina, B.; Beria, I.; Alli, C.; Alzani, R.; Avanzi, N.; Ballinari, D.; Cappella, P.; Caruso, M.; Casolaro, A.; Ciavolella, A.; et al. NMSP937, an orally available, specific small-molecule polo-like kinase 1 inhibitor with antitumor activity in solid and hematologic malignancies. Mol. Cancer Ther. 2012, 11, 1006-1016. [CrossRef]

125. Weiss, G.J.; Jameson, G.; Von Hoff, D.D.; Valsasina, B.; Davite, C.; Di Giulio, C.; Fiorentini, F.; Alzani, R.; Carpinelli, P.; Di Sanzo, A.; et al. Phase I dose escalation study of NMS-1286937, an orally available Polo-Like Kinase 1 inhibitor, in patients with advanced or metastatic solid tumors. Invest. New Drugs 2018, 36, 85-95. [CrossRef]

126. Zeidan, A.M.; Ridinger, M.; Lin, T.L.; Becker, P.S.; Schiller, G.J.; Patel, P.A.; Spira, A.I.; Tsai, M.L.; Samuelsz, E.; Silberman, S.L.; et al. A Phase Ib Study of Onvansertib, a Novel Oral PLK1 Inhibitor, in Combination Therapy for Patients with Relapsed or Refractory Acute Myeloid Leukemia. Clin. Cancer Res. 2020, 26, 6132-6140. [CrossRef]

127. Byrum, A.K.; Vindigni, A.; Mosammaparast, N. Defining and Modulating 'BRCAness'. Trends Cell Biol. 2019, 29, 740-751. [CrossRef]

128. Abkevich, V.; Timms, K.M.; Hennessy, B.T.; Potter, J.; Carey, M.S.; Meyer, L.A.; Smith-McCune, K.; Broaddus, R.; Lu, K.H.; Chen, J.; et al. Patterns of genomic loss of heterozygosity predict homologous recombination repair defects in epithelial ovarian cancer. Br. J. Cancer 2012, 107, 1776-1782. [CrossRef]

129. Popova, T.; Manie, E.; Rieunier, G.; Caux-Moncoutier, V.; Tirapo, C.; Dubois, T.; Delattre, O.; Sigal-Zafrani, B.; Bollet, M.; Longy, M.; et al. Ploidy and large-scale genomic instability consistently identify basal-like breast carcinomas with BRCA1/2 inactivation. Cancer Res. 2012, 72, 5454-5462. [CrossRef]

130. Birkbak, N.J.; Wang, Z.C.; Kim, J.Y.; Eklund, A.C.; Li, Q.; Tian, R.; Bowman-Colin, C.; Li, Y.; Greene-Colozzi, A.; Iglehart, J.D.; et al. Telomeric allelic imbalance indicates defective DNA repair and sensitivity to DNA-damaging agents. Cancer Discov. 2012, 2, 366-375. [CrossRef]

131. Timms, K.M.; Abkevich, V.; Hughes, E.; Neff, C.; Reid, J.; Morris, B.; Kalva, S.; Potter, J.; Tran, T.V.; Chen, J.; et al. Association of BRCA1/2 defects with genomic scores predictive of DNA damage repair deficiency among breast cancer subtypes. Breast Cancer Res. 2014, 16, 475. [CrossRef] [PubMed]

132. Telli, M.L.; Timms, K.M.; Reid, J.; Hennessy, B.; Mills, G.B.; Jensen, K.C.; Szallasi, Z.; Barry, W.T.; Winer, E.P.; Tung, N.M.; et al. Homologous Recombination Deficiency (HRD) Score Predicts Response to Platinum-Containing Neoadjuvant Chemotherapy in Patients with Triple-Negative Breast Cancer. Clin. Cancer Res. 2016, 22, 3764-3773. [CrossRef] [PubMed]

133. Frampton, G.M.; Fichtenholtz, A.; Otto, G.A.; Wang, K.; Downing, S.R.; He, J.; Schnall-Levin, M.; White, J.; Sanford, E.M.; An, P.; et al. Development and validation of a clinical cancer genomic profiling test based on massively parallel DNA sequencing. Nat. Biotechnol. 2013, 31, 1023-1031. [CrossRef] [PubMed]

134. Swisher, E.M.; Lin, K.K.; Oza, A.M.; Scott, C.L.; Giordano, H.; Sun, J.; Konecny, G.E.; Coleman, R.L.; Tinker, A.V.; O'Malley, D.M.; et al. Rucaparib in relapsed, platinum-sensitive high-grade ovarian carcinoma (ARIEL2 Part 1): An international, multicentre, open-label, phase 2 trial. Lancet Oncol. 2017, 18, 75-87. [CrossRef]

135. Miller, R.E.; Leary, A.; Scott, C.L.; Serra, V.; Lord, C.J.; Bowtell, D.; Chang, D.K.; Garsed, D.W.; Jonkers, J.; Ledermann, J.A.; et al ESMO recommendations on predictive biomarker testing for homologous recombination deficiency and PARP inhibitor benefit in ovarian cancer. Ann. Oncol. 2020, 31, 1606-1622. [CrossRef] [PubMed]

136. Ngoi, N.Y.L.; Tan, D.S.P. The role of homologous recombination deficiency testing in ovarian cancer and its clinical implications: Do we need it? ESMO Open 2021, 6, 100144. [CrossRef] [PubMed]

137. Polak, P.; Kim, J.; Braunstein, L.Z.; Karlic, R.; Haradhavala, N.J.; Tiao, G.; Rosebrock, D.; Livitz, D.; Kubler, K.; Mouw, K.W.; et al. A mutational signature reveals alterations underlying deficient homologous recombination repair in breast cancer. Nat. Genet. 2017, 49, 1476-1486. [CrossRef]

138. Gulhan, D.C.; Lee, J.J.; Melloni, G.E.M.; Cortes-Ciriano, I.; Park, P.J. Detecting the mutational signature of homologous recombination deficiency in clinical samples. Nat. Genet. 2019, 51, 912-919. [CrossRef]

139. Farkkila, A.; Gulhan, D.C.; Casado, J.; Jacobson, C.A.; Nguyen, H.; Kochupurakkal, B.; Maliga, Z.; Yapp, C.; Chen, Y.A.; Schapiro, D.; et al. Immunogenomic profiling determines responses to combined PARP and PD-1 inhibition in ovarian cancer. Nat. Commun. 2020, 11, 1459. [CrossRef]

140. Cleary, J.M.; Aguirre, A.J.; Shapiro, G.I.; D’Andrea, A.D. Biomarker-Guided Development of DNA Repair Inhibitors. Mol. Cell 2020, 78, 1070-1085. [CrossRef]

141. Yazinski, S.A.; Comaills, V.; Buisson, R.; Genois, M.M.; Nguyen, H.D.; Ho, C.K.; Todorova Kwan, T.; Morris, R.; Lauffer, S.; Nussenzweig, A.; et al. ATR inhibition disrupts rewired homologous recombination and fork protection pathways in PARP inhibitor-resistant BRCA-deficient cancer cells. Genes Dev. 2017, 31, 318-332. [CrossRef]

142. Kim, H.; George, E.; Ragland, R.; Rafail, S.; Zhang, R.; Krepler, C.; Morgan, M.; Herlyn, M.; Brown, E.; Simpkins, F. Targeting the ATR/CHK1 Axis with PARP Inhibition Results in Tumor Regression in BRCA-Mutant Ovarian Cancer Models. Clin. Cancer Res. 2017, 23, 3097-3108. [CrossRef] [PubMed]

143. Parmar, K.; Kochupurakkal, B.S.; Lazaro, J.B.; Wang, Z.C.; Palakurthi, S.; Kirschmeier, P.T.; Yang, C.; Sambel, L.A.; Farkkila, A.; Reznichenko, E.; et al. The CHK1 Inhibitor Prexasertib Exhibits Monotherapy Activity in High-Grade Serous Ovarian Cancer Models and Sensitizes to PARP Inhibition. Clin. Cancer Res. 2019, 25, 6127-6140. [CrossRef] [PubMed] 
144. Tentori, L.; Lacal, P.M.; Muzi, A.; Dorio, A.S.; Leonetti, C.; Scarsella, M.; Ruffini, F.; Xu, W.; Min, W.; Stoppacciaro, A.; et al. Poly(ADP-ribose) polymerase (PARP) inhibition or PARP-1 gene deletion reduces angiogenesis. Eur. J. Cancer 2007, 43, 2124-2133. [CrossRef]

145. Chan, N.; Bristow, R.G. "Contextual" synthetic lethality and/or loss of heterozygosity: Tumor hypoxia and modification of DNA repair. Clin. Cancer Res. 2010, 16, 4553-4560. [CrossRef] [PubMed]

146. Liu, J.F.; Barry, W.T.; Birrer, M.; Lee, J.M.; Buckanovich, R.J.; Fleming, G.F.; Rimel, B.J.; Buss, M.K.; Nattam, S.R.; Hurteau, J.; et al. Overall survival and updated progression-free survival outcomes in a randomized phase II study of combination cediranib and olaparib versus olaparib in relapsed platinum-sensitive ovarian cancer. Ann. Oncol. 2019, 30, 551-557. [CrossRef]

147. Mirza, M.R.; Avall Lundqvist, E.; Birrer, M.J.; dePont Christensen, R.; Nyvang, G.B.; Malander, S.; Anttila, M.; Werner, T.L.; Lund, B.; Lindahl, G.; et al. Niraparib plus bevacizumab versus niraparib alone for platinum-sensitive recurrent ovarian cancer (NSGO-AVANOVA2/ENGOT-ov24): A randomised, phase 2, superiority trial. Lancet Oncol. 2019, 20, 1409-1419. [CrossRef]

148. Elyashiv, O.; Ledermann, J.; Parmar, G.; Farrelly, L.; Counsell, N.; Feeney, A.; El-Khouly, F.; Macdonald, I.; Neto, A.; Arthur-Darkwa, E.; et al. ICON 9-an international phase III randomized study to evaluate the efficacy of maintenance therapy with olaparib and cediranib or olaparib alone in patients with relapsed platinum-sensitive ovarian cancer following a response to platinum-based chemotherapy. Int. J. Gynecol. Cancer 2021, 31, 134-138. [CrossRef]

149. Kim, J.W.; Cardin, D.B.; Vaishampayan, U.N.; Kato, S.; Grossman, S.R.; Glazer, P.M.; Shyr, Y.; Ivy, S.P.; LoRusso, P.M. Clinical Activity and Safety of Cediranib and Olaparib Combination in Patients with Metastatic Pancreatic Ductal Adenocarcinoma without BRCA Mutation. Oncologist 2021, 26, e1104-e1109. [CrossRef]

150. Kumar, A.; Fernandez-Capetillo, O.; Carrera, A.C. Nuclear phosphoinositide 3-kinase beta controls double-strand break DNA repair. Proc. Natl. Acad. Sci. USA 2010, 107, 7491-7496. [CrossRef]

151. Ibrahim, Y.H.; Garcia-Garcia, C.; Serra, V.; He, L.; Torres-Lockhart, K.; Prat, A.; Anton, P.; Cozar, P.; Guzman, M.; Grueso, J.; et al. PI3K inhibition impairs BRCA1/2 expression and sensitizes BRCA-proficient triple-negative breast cancer to PARP inhibition. Cancer Discov. 2012, 2, 1036-1047. [CrossRef] [PubMed]

152. Juvekar, A.; Burga, L.N.; Hu, H.; Lunsford, E.P.; Ibrahim, Y.H.; Balmana, J.; Rajendran, A.; Papa, A.; Spencer, K.; Lyssiotis, C.A.; et al. Combining a PI3K inhibitor with a PARP inhibitor provides an effective therapy for BRCA1-related breast cancer. Cancer Discov. 2012, 2, 1048-1063. [CrossRef] [PubMed]

153. Matulonis, U.A.; Wulf, G.M.; Barry, W.T.; Birrer, M.; Westin, S.N.; Farooq, S.; Bell-McGuinn, K.M.; Obermayer, E.; Whalen, C.; Spagnoletti, T.; et al. Phase I dose escalation study of the PI3kinase pathway inhibitor BKM120 and the oral poly (ADP ribose) polymerase (PARP) inhibitor olaparib for the treatment of high-grade serous ovarian and breast cancer. Ann. Oncol. 2017, 28, 512-518. [CrossRef] [PubMed]

154. Konstantinopoulos, P.A.; Barry, W.T.; Birrer, M.; Westin, S.N.; Cadoo, K.A.; Shapiro, G.I.; Mayer, E.L.; O'Cearbhaill, R.E.; Coleman, R.L.; Kochupurakkal, B.; et al. Olaparib and alpha-specific PI3K inhibitor alpelisib for patients with epithelial ovarian cancer: A dose-escalation and dose-expansion phase 1b trial. Lancet Oncol. 2019, 20, 570-580. [CrossRef]

155. Yap, T.A.; Kristeleit, R.; Michalarea, V.; Pettitt, S.J.; Lim, J.S.J.; Carreira, S.; Roda, D.; Miller, R.; Riisnaes, R.; Miranda, S.; et al. Phase I Trial of the PARP Inhibitor Olaparib and AKT Inhibitor Capivasertib in Patients with BRCA1/2- and Non-BRCA1/2-Mutant Cancers. Cancer Discov. 2020, 10, 1528-1543. [CrossRef]

156. Westin, S.N.; Labrie, M.; Litton, J.K.; Blucher, A.; Fang, Y.; Vellano, C.P.; Marszalek, J.R.; Feng, N.; Ma, X.; Creason, A.; et al. Phase Ib Dose Expansion and Translational Analyses of Olaparib in Combination with Capivasertib in Recurrent Endometrial, Triple-Negative Breast, and Ovarian Cancer. Clin. Cancer Res. 2021, 27, 6354-6365. [CrossRef]

157. Goodwin, J.F.; Schiewer, M.J.; Dean, J.L.; Schrecengost, R.S.; de Leeuw, R.; Han, S.; Ma, T.; Den, R.B.; Dicker, A.P.; Feng, F.Y.; et al A hormone-DNA repair circuit governs the response to genotoxic insult. Cancer Discov. 2013, 3, 1254-1271. [CrossRef]

158. Polkinghorn, W.R.; Parker, J.S.; Lee, M.X.; Kass, E.M.; Spratt, D.E.; Iaquinta, P.J.; Arora, V.K.; Yen, W.F.; Cai, L.; Zheng, D.; et al. Androgen receptor signaling regulates DNA repair in prostate cancers. Cancer Discov. 2013, 3, 1245-1253. [CrossRef]

159. Asim, M.; Tarish, F.; Zecchini, H.I.; Sanjiv, K.; Gelali, E.; Massie, C.E.; Baridi, A.; Warren, A.Y.; Zhao, W.; Ogris, C.; et al. Synthetic lethality between androgen receptor signalling and the PARP pathway in prostate cancer. Nat. Commun. 2017, 8, 374. [CrossRef]

160. Li, L.; Karanika, S.; Yang, G.; Wang, J.; Park, S.; Broom, B.M.; Manyam, G.C.; Wu, W.; Luo, Y.; Basourakos, S.; et al. Androgen receptor inhibitor-induced "BRCAness" and PARP inhibition are synthetically lethal for castration-resistant prostate cancer. Sci. Signal 2017, 10, eaam7479. [CrossRef]

161. Karanika, S.; Karantanos, T.; Li, L.; Wang, J.; Park, S.; Yang, G.; Zuo, X.; Song, J.H.; Maity, S.N.; Manyam, G.C.; et al. Targeting DNA Damage Response in Prostate Cancer by Inhibiting Androgen Receptor-CDC6-ATR-Chk1 Signaling. Cell Rep. 2017, 18, 1970-1981. [CrossRef] [PubMed]

162. Clarke, N.; Wiechno, P.; Alekseev, B.; Sala, N.; Jones, R.; Kocak, I.; Chiuri, V.E.; Jassem, J.; Flechon, A.; Redfern, C.; et al Olaparib combined with abiraterone in patients with metastatic castration-resistant prostate cancer: A randomised, double-blind, placebo-controlled, phase 2 trial. Lancet Oncol. 2018, 19, 975-986. [CrossRef]

163. Sun, C.; Fang, Y.; Yin, J.; Chen, J.; Ju, Z.; Zhang, D.; Chen, X.; Vellano, C.P.; Jeong, K.J.; Ng, P.K.; et al. Rational combination therapy with PARP and MEK inhibitors capitalizes on therapeutic liabilities in RAS mutant cancers. Sci. Transl. Med. 2017, 9, eaal5148. [CrossRef] [PubMed]

164. Le, D.T.; Durham, J.N.; Smith, K.N.; Wang, H.; Bartlett, B.R.; Aulakh, L.K.; Lu, S.; Kemberling, H.; Wilt, C.; Luber, B.S.; et al. Mismatch repair deficiency predicts response of solid tumors to PD-1 blockade. Science 2017, 357, 409-413. [CrossRef] [PubMed] 
165. Marabelle, A.; Fakih, M.; Lopez, J.; Shah, M.; Shapira-Frommer, R.; Nakagawa, K.; Chung, H.C.; Kindler, H.L.; Lopez-Martin, J.A.; Miller, W.H., Jr.; et al. Association of tumour mutational burden with outcomes in patients with advanced solid tumours treated with pembrolizumab: Prospective biomarker analysis of the multicohort, open-label, phase 2 KEYNOTE-158 study. Lancet Oncol. 2020, 21, 1353-1365. [CrossRef]

166. Teo, M.Y.; Seier, K.; Ostrovnaya, I.; Regazzi, A.M.; Kania, B.E.; Moran, M.M.; Cipolla, C.K.; Bluth, M.J.; Chaim, J.; Al-Ahmadie, H.; et al. Alterations in DNA Damage Response and Repair Genes as Potential Marker of Clinical Benefit From PD-1/PD-L1 Blockade in Advanced Urothelial Cancers. J. Clin. Oncol. 2018, 36, 1685-1694. [CrossRef]

167. Li, A.; Yi, M.; Qin, S.; Chu, Q.; Luo, S.; Wu, K. Prospects for combining immune checkpoint blockade with PARP inhibition. J. Hematol. Oncol. 2019, 12, 98. [CrossRef]

168. Pantelidou, C.; Sonzogni, O.; De Oliveria Taveira, M.; Mehta, A.K.; Kothari, A.; Wang, D.; Visal, T.; Li, M.K.; Pinto, J.; Castrillon, J.A.; et al. PARP Inhibitor Efficacy Depends on CD8(+) T-cell Recruitment via Intratumoral STING Pathway Activation in BRCA-Deficient Models of Triple-Negative Breast Cancer. Cancer Discov. 2019, 9, 722-737. [CrossRef]

169. Sen, T.; Rodriguez, B.L.; Chen, L.; Corte, C.M.D.; Morikawa, N.; Fujimoto, J.; Cristea, S.; Nguyen, T.; Diao, L.; Li, L.; et al. Targeting DNA Damage Response Promotes Antitumor Immunity through STING-Mediated T-cell Activation in Small Cell Lung Cancer. Cancer Discov. 2019, 9, 646-661. [CrossRef]

170. Shen, J.; Zhao, W.; Ju, Z.; Wang, L.; Peng, Y.; Labrie, M.; Yap, T.A.; Mills, G.B.; Peng, G. PARPi Triggers the STING-Dependent Immune Response and Enhances the Therapeutic Efficacy of Immune Checkpoint Blockade Independent of BRCAness. Cancer Res. 2019, 79, 311-319. [CrossRef]

171. Kwon, J.; Bakhoum, S.F. The Cytosolic DNA-Sensing cGAS-STING Pathway in Cancer. Cancer Discov. 2020, 10, 26-39. [CrossRef] [PubMed]

172. Jiao, S.; Xia, W.; Yamaguchi, H.; Wei, Y.; Chen, M.K.; Hsu, J.M.; Hsu, J.L.; Yu, W.H.; Du, Y.; Lee, H.H.; et al. PARP Inhibitor Upregulates PD-L1 Expression and Enhances Cancer-Associated Immunosuppression. Clin. Cancer Res. 2017, 23, 3711-3720. [CrossRef] [PubMed]

173. Sato, H.; Niimi, A.; Yasuhara, T.; Permata, T.B.M.; Hagiwara, Y.; Isono, M.; Nuryadi, E.; Sekine, R.; Oike, T.; Kakoti, S.; et al DNA double-strand break repair pathway regulates PD-L1 expression in cancer cells. Nat. Commun. 2017, 8, 1751. [CrossRef]

174. Domchek, S.M.; Postel-Vinay, S.; Im, S.A.; Park, Y.H.; Delord, J.P.; Italiano, A.; Alexandre, J.; You, B.; Bastian, S.; Krebs, M.G.; et al. Olaparib and durvalumab in patients with germline BRCA-mutated metastatic breast cancer (MEDIOLA): An open-label, multicentre, phase 1/2, basket study. Lancet Oncol. 2020, 21, 1155-1164. [CrossRef]

175. Drew, Y.; Kaufman, B.; Banerjee, S.; Lortholary, A.; Hong, S.H.; Park, Y.H.; Zimmermann, S.; Roxburgh, P.; Ferguson, M.; Alvarez, R.H.; et al. Phase II study of olaparib + durvalumab (MEDIOLA): Updated results in germline BRCA-mutated platinumsensitive relapsed (PSR) ovarian cancer (OC). Ann. Oncol. 2019, 30, v485-v486. [CrossRef]

176. Bang, Y.-J.; Kaufman, B.; Geva, R.; Stemmer, S.M.; Hong, S.-H.; Lee, J.-S.; Domchek, S.M.; Lanasa, M.C.; Tang, M.; Gresty, C.; et al. An open-label, phase II basket study of olaparib and durvalumab (MEDIOLA): Results in patients with relapsed gastric cancer. J. Clin. Oncol. 2019, 37, 140. [CrossRef]

177. Thomas, A.; Vilimas, R.; Trindade, C.; Erwin-Cohen, R.; Roper, N.; Xi, L.; Krishnasamy, V.; Levy, E.; Mammen, A.; Nichols, S.; et al. Durvalumab in Combination with Olaparib in Patients with Relapsed SCLC: Results from a Phase II Study. J. Thorac. Oncol. 2019, 14, 1447-1457. [CrossRef] [PubMed]

178. Karzai, F.; VanderWeele, D.; Madan, R.A.; Owens, H.; Cordes, L.M.; Hankin, A.; Couvillon, A.; Nichols, E.; Bilusic, M.; Beshiri, M.L.; et al. Activity of durvalumab plus olaparib in metastatic castration-resistant prostate cancer in men with and without DNA damage repair mutations. J. Immunother. Cancer 2018, 6, 141. [CrossRef]

179. Konstantinopoulos, P.A.; Waggoner, S.; Vidal, G.A.; Mita, M.; Moroney, J.W.; Holloway, R.; Van Le, L.; Sachdev, J.C.; Chapman-Davis, E.; Colon-Otero, G.; et al. Single-Arm Phases 1 and 2 Trial of Niraparib in Combination With Pembrolizumab in Patients With Recurrent Platinum-Resistant Ovarian Carcinoma. JAMA Oncol. 2019, 5, 1141-1149. [CrossRef]

180. Vinayak, S.; Tolaney, S.M.; Schwartzberg, L.S.; Mita, M.M.; McCann, G.A.-L.; Tan, A.R.; Hendrickson, A.E.W.; Forero-Torres, A.; Anders, C.K.; Wulf, G.M.; et al. TOPACIO/Keynote-162: Niraparib + pembrolizumab in patients (pts) with metastatic triplenegative breast cancer (TNBC), a phase 2 trial. J. Clin. Oncol. 2018, 36, 1011. [CrossRef]

181. Goff, P.H.; Bhakuni, R.; Pulliam, T.; Lee, J.H.; Hall, E.T.; Nghiem, P. Intersection of Two Checkpoints: Could Inhibiting the DNA Damage Response Checkpoint Rescue Immune Checkpoint-Refractory Cancer? Cancers 2021, 13, 3415. [CrossRef] [PubMed] 